\title{
Marine Fungi: A Source of Potential Anticancer Compounds
}

\author{
Sunil K. Deshmukh ${ }^{1 *}$, Ved Prakash ${ }^{2}$ and Nihar Ranjan ${ }^{1 *}$ \\ ${ }^{1}$ TERI-Deakin Nano Biotechnology Centre, The Energy and Resources Institute, New Delhi, India, ${ }^{2}$ Department of \\ Biotechnology, Motilal Nehru National Institute of Technology, Allahabad, India
}

OPEN ACCESS

Edited by:

Bhim Pratap Singh,

Mizoram University, India

Reviewed by:

Giovanna Cristina Varese, Università degli Studi di Torino, Italy Antje Labes,

Fachhochschule Flensburg, Germany

${ }^{*}$ Correspondence:

Sunil K. Deshmukh

sunil.deshmukh@teri.res.in Nihar Ranjan

nihar.ranjan@teri.res.in

Specialty section:

This article was submitted to Microbiotechnology, Ecotoxicology and Bioremediation,

a section of the journal

Frontiers in Microbiology

Received: 18 April 2017 Accepted: 06 December 2017

Published: 05 January 2018

Citation:

Deshmukh SK, Prakash V and Ranjan N (2018) Marine Fungi: A

Source of Potential Anticancer Compounds. Front. Microbiol. 8:2536.

doi: 10.3389/fmicb.2017.02536
Metabolites from marine fungi have hogged the limelight in drug discovery because of their promise as therapeutic agents. A number of metabolites related to marine fungi have been discovered from various sources which are known to possess a range of activities as antibacterial, antiviral and anticancer agents. Although, over a thousand marine fungi based metabolites have already been reported, none of them have reached the market yet which could partly be related to non-comprehensive screening approaches and lack of sustained lead optimization. The origin of these marine fungal metabolites is varied as their habitats have been reported from various sources such as sponge, algae, mangrove derived fungi, and fungi from bottom sediments. The importance of these natural compounds is based on their cytotoxicity and related activities that emanate from the diversity in their chemical structures and functional groups present on them. This review covers the majority of anticancer compounds isolated from marine fungi during 2012-2016 against specific cancer cell lines.

Keywords: marine fungi, deep sea fungi, cytotoxic compounds, mangroove associated fungi, sponge associated fungi

\section{INTRODUCTION}

Marine fungi are important source of secondary metabolites useful for the drug discovery purposes. Even though marine fungi are less explored in comparison to their terrestrial counterparts, a number of useful hits have been obtained from the drug discovery perspective adding to their importance in the natural product discovery (Molinski et al., 2009; Butler et al., 2014), which have yielded a wide range of chemically diverse agents with antibacterial, antiviral and anticancer properties in animal systems. Starting with the celebrated example of cephalosporins, marine fungi have provided unique chemical skeletons that could be used to develop drugs of clinical importance (Bhadury et al., 2006; Saleem et al., 2007; Javed et al., 2011; Sithranga and Kathiresan, 2011). Fungi, in general, have been generous source of drugs as evidenced by the isolation of many drugs in use such as paclitaxel, camptothecin, vincristine, torreyanic acid and cytarabine to name a few. In this light, marine are important not just from the perspective of new drugs but also as a source of new scaffolds that can be modified further to obtain the desired action. Despite significant progress in the drug discovery that has provided treatment for some major ailments, minor infections, and epidemics; new drugs are required to combat global resistance to drugs for existing diseases and new infections that have been reported in recent times (such as SARS, dengue and Zika 
viruses). In addition to drug resistance in diseases such as tuberculosis and malaria, cancer \& HIV-AIDS (Passaes and SáezCirión, 2014) have been biological targets with limited success toward therapeutics development.

In addition to terrestrial sources, oceans have been a huge reservoir of a variety of biologically active compounds, which have often been the resulting metabolite of marine life (König et al., 2006; Chen G. et al., 2014; Agrawal et al., 2016; Deshmukh et al., 2017). Though, why marine fungi produce such complex and diverse set of metabolites in not fairly understood, it is largely assumed that they play key roles in chemical defense and communication. The biosynthesis of these metabolites in dependent on ecological, physical and biological factors and, therefore, small changes in these conditions can generate entirely new set of metabolites (Pejin and Maja, 2017). The contribution of marine based therapeutics can be gauged from the fact that during 1981-2002, more than half of the FDA approved drugs had originated from marine life. Most of the marine based drugs have come from invertebrates (sponges, tunicates, mollusks, and bryozoans); two-thirds of which, belong to the class of non-ribosomal peptides. Some of these are already in the market (Polymixin B, pristinamycin, gramicidin, vancomycin, bleomycin, actinomycin D) as antibiotic and anti-cancer agents while several others are in clinical trials (Manoalide, discodermolide) (Singh et al., 2008). In this regard, there have not been many reports of drugs from marine fungi that are used clinically which can be partly attributed to lack of systematic and comprehensive approaches as well as lack of optimization which has precluded a large number of potential hits from becoming actual drugs. Therefore, metabolites marine fungi constitute a group of underrepresented resource for discovering novel therapeutics (Imhoff, 2016).

Several classes of chemically distinct metabolites from marine fungi have been reported in recent years which have a wide range of activities against different targets (Wu et al., 2015, 2016). From marine fungi alone, over thousand metabolites have been reported to have potential to be developed as drugs (Gomes et al., 2015), with several as anticancer compounds (please also see a detailed review, Bugni and Ireland, 2004 for historical inputs, taxonomy, ecological roles, distribution and chemistry as well biological activities of marine fungi), none of these have reached the market till now. However, for majority of these findings, complete taxonomy studies, biological targets and modes of interaction have not been identified yet. Due to these limitations, in this review, we cover anticancer compounds reported from marine fungi obtained from different sources such as deep-sea sediments, algae, sponge, mangrove endophytic and other marine fungi, discovered during 2012-2016 with a focus on summarizing the important findings and highlighting the lead compounds. Wherever explored, the biological targets and efficacies have been discussed as well. Novel anticancer compounds reported from marine fungi are given in Supplementary Table 1. They are arranged on the basis of sources the fungi isolated.

\section{METABOLITES ISOLATED FROM DEEP-SEA SEDIMENT FUNGI}

Deep-sea fungi inhabit at depths of thousand meters or below the surface (Swathi et al., 2013) where the sea environments are extreme; which are typically characterized by the absence of sunlight irradiation, predominantly low temperature, high hydrostatic pressure, and oligotrophy. Many reports indicate abundance and diversity of fungi in these environments (Hua et al., 2011; Mahé et al., 2013). Here, we present an account of metabolites reported from the deep-sea fungi during 2012-2016 that have displayed anticancer activities in various cell lines.

Linear peptides, simplicilliumtides A, E, G, and $\mathrm{H}$ (1-4; Figure 1) were isolated from a culture broth of the deep-seaderived fungal strain Simplicillium obclavatum EIODSF 020e collected in the East Indian Ocean. Simplicilliumtides A and G showed weak cytotoxicity toward human leukemia HL-60 cell line with $\mathrm{IC}_{50}$ values of 64.7 and $100 \mu \mathrm{M}$, and simplicilliumtides $\mathrm{E}$ and $\mathrm{H}$ showed weak cytotoxicity toward K562 cell line with $\mathrm{IC}_{50}$ values of 39.4 and $73.5 \mu \mathrm{M}$ (Liang et al., 2016). Using a combination of fermentation and subsequent chromatographic separation, acaromycin A (5) and (+)-cryptosporin (6; Figure 1) were isolated from the deep-sea derived fungus Acaromyces ingoldii FS121 which was obtained from the South Sea in China. Using a combinaion of one and two-dimensional NMR as well as mass spectroscopic techniques, the chemical structures were elucidated and the absolute configuration was further determined by circular dichroism (CD) experiments. Compounds (5) and (6) exhibited considerable growth inhibition against tumor cell lines MCF-7, NCI-H460, SF-268, and HepG-2 with $\mathrm{IC}_{50}$ values $<10 \mu \mathrm{M}$. The inhibitory effect of compound (5) against MCF7 cell line was comparable to cytoxicity of cisplatin which was used as a positive control (Gao et al., 2016a). A new tetranorlabdane diterpenoid, asperolide E (7; Figure 1) was isolated from the deep sea sediment-derived fungus Aspergillus wentii SD-310. The cytotoxicity of compound (7) was evaluated against HeLa, MCF-7, and NCI-H446 cell lines which showed $\mathrm{IC}_{50}$ values of $10.0,11.0$, and $16.0 \mu \mathrm{M}$ respectively (Li X.-D. et al., 2016).

Asperethers A-E (8-12; Figure 1), five new 20-norisopimarane diterpenoids having a 14,16-cyclic ether unit and a unique 6/6/6/5 tetracyclic skeleton, were discovered from the culture extract of Aspergillus wentii SD-310 from the deep-sea sediment sample. The chemical structure of these compounds was determined by mass spectrometry and NMR techniques $\left({ }^{1} \mathrm{H}\right.$ NMR, COSY, HSQC, HMBC) and the absolute configurations were supported by NOESY, X-ray crystallography, CD and computational methods. Compounds (8-12) displayed cytotoxic activities against $\mathrm{A} 549$ cell line with the $\mathrm{IC}_{50}$ values of $20,16,19$, 17 , and $20 \mu \mathrm{M}$, respectively, which were moderately higher than the positive control Adriamycin (Li X. et al., 2016).

Circumdatin G (13; Figure 1), was isolated from the culture of the deep-sea fungus Aspergillus westerdijkiae SCSIO 05233 which was isolated from a sediment sample in the South China Sea. Spectroscopic analysis using mass spectrometry and a variety of one and two-dimensional NMR techniques (DEPT, HMBC) 
<smiles>CC(C)C[C@H](NC(=O)[C@H](Cc1ccccc1)N(C)C(=O)[C@@H](N)C(C)C)C(=O)Nc1ccccc1C(=O)O</smiles>

Simplicilliumtide A (1)<smiles>CC[C@H](C)[C@H](NC(C)=O)C(=O)N(C)[C@@H](Cc1ccccc1)C(=O)O</smiles>

Simplicilliumtide $\mathrm{H}(\mathbf{4})$<smiles>[R2]C[C@]1(C)c2cc(O)c3c(c2CC[C@@H]1[R])CC[C@@]1(C)[C@@H]3OC[C@@H]1O</smiles>

Asperethers A-E (8-12)<smiles>CC(O)c1nc2ccccc2c(=O)[nH]1</smiles>

Chrysogine (15)<smiles>CC(=O)CC1=C[C@H](C(C)O)OC1=O</smiles>

Aspiketolactonol (19)<smiles>CC(O)CC1=C[C@H]([C@@H](C)O)OC1=O</smiles>

6/7: $9 \mathrm{R}^{\star} / 9 \mathrm{~S}^{*}$

Aspilactonols E,F $(\mathbf{2 4 , 2 5 )}$<smiles>CC(O)/C=C(\C=C\[C@H](C)O)CO</smiles>

A: $2 S$; $B: 2 R$

Aspinotriol A, B $(30,31)$
8. $\mathrm{R}_{1}=\mathrm{OH}, \mathrm{R}_{2}=\mathrm{H}_{\text {, (15S) }}$

9. $\mathrm{R}_{1}=\mathrm{H}, \mathrm{R}_{2}=\mathrm{H}$, (15S)

10. $R_{1}=H_{1}, R_{2}=O H$, (15S)

11. $R_{1}=H, R_{2}=O A C$, (15S)

12, $R_{1}=H, R_{2}=O H,(15 R)$<smiles>C=CC(C)(C)C12C=C(O)C(=O)N3/C(=C/c4c[nH]cn4)C(=O)N(OC)C34N(OC)c3ccccc3C41C2(C)C</smiles>

Circumdatin G (13)<smiles>C=C(C)[C@H]1C[C@]2(C)C(=C[C@H](O)C[C@H]2C)C[C@H]1O</smiles>

Compound (17)<smiles>CC(O)C(O)C1=CC(O)(C(C)O)OC1=O</smiles>

B: 8 S,9R; C: $8 \mathrm{R}, 9 \mathrm{~S}$

Aspilactonols B, C $(21,22)$<smiles>C[C@H]1C=C(CCO)C(=O)O1</smiles>

\section{Compound (28)}<smiles>O=C1N[C@H](Cc2ccccc2)C(=O)N2CCC[C@H]12</smiles>

Compound (33)<smiles>CC[C@H](C)[C@H](NC(C)=O)C(=O)N(C)[C@H](Cc1ccc(O)cc1)C(=O)O</smiles>

Simplicilliumtide G (2)<smiles>C[C@]12C=C[C@H](O)[C@]34CC(=O)OCC3=C[C@H]1OC(=O)[C@@H]42</smiles>

Asperolide $\mathrm{E}$ (7)<smiles>[C-]#[N+]C(=Cc1ccc(O)cc1)/C(=C/c1ccc(O)cc1)[N+]#[C-]</smiles>

Xanthocillin X (14)<smiles>CO[C@]12C=C3C([C@]4(C)CO[C@H](C)CO4)O[C@H]3[C@@H](C(=O)O)[C@@H](C)[C@]1(C)C2</smiles>

Eremofortine C (18)<smiles>CO[C@@H](C1=C[C@](O)(C(C)O)OC1=O)[C@@H](C)O</smiles>

Aspilactonol D (23)<smiles>[R]O[Sb]([R])(C)[Se][R]</smiles>

Aspyronol,

dihydroaspyrone $(26,29)$<smiles>O=C1N[C@H](Cc2ccc(O)cc2)C(=O)N2CCC[C@H]12</smiles> 
<smiles>O=C1CC[C@H](C(=O)OCCc2ccccc2)N1</smiles>

Compound (35)<smiles>CCC(C)[C@H]1NC(=O)[C@@H]2CCCN2C1=O</smiles>

Compound (36)<smiles>CC(C)C1NC(=O)[C@@H]2CCCN2C1=O</smiles>

Compound (37)

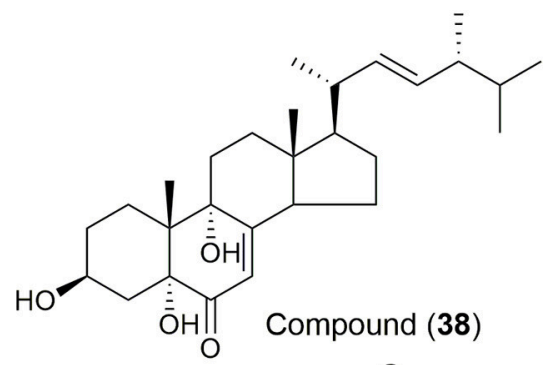<smiles>COC(=O)[C@H]1c2c(oc3cc(CO)cc(O)c3c2=O)C=CC1F</smiles><smiles>[14CH3][14C](O)=[14C]O</smiles>
$41 \mathrm{R}=\beta-\mathrm{OH}$ Engyodontiumones $\mathrm{H}$ (39) Polyketide (40)<smiles>CC(=O)O[C@H]1C=C(Cl)C2=CC(=O)C(O)=C[C@]2(C)[C@H]1C</smiles>

Compound (41)<smiles>C[C@@]12C3=CC(=O)OCC3=C[C@@H]3OC(=O)[C@](C)([C@@H]31)[C@H]1O[C@@H]1[C@@H]2O</smiles>

Wentilactone A (42)<smiles>C[C@]12C[C@H](O)C[C@@]3(C)C4=CC(=O)OCC4=C[C@H](OC1=O)C23</smiles>

Wentilactone B (43)

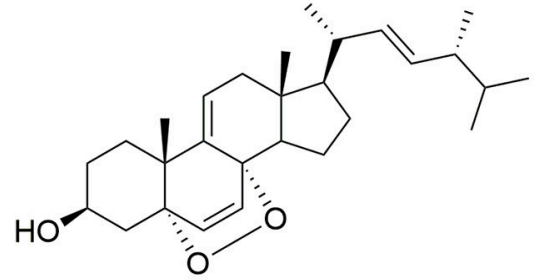

Compound (44)<smiles>CC(C)[C@H](C)/C=C/[C@H](C)[C@H]1CCC2[C@@]1(C)CCC1[C@]34C=C[C@@]2(OO3)[C@]1(C)CC[C@H](O)C4</smiles>

Ergosterol peroxide (45)<smiles>CC(C)OC(=O)OC(C)(C)C</smiles>

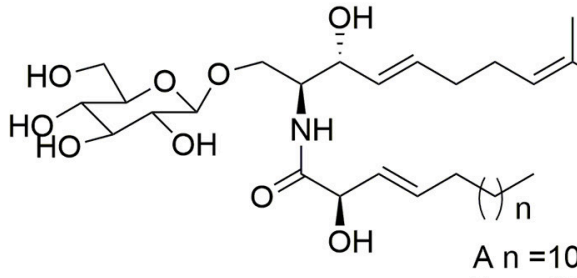

Cerebroside A, B $(\mathbf{4 7 , 4 8 )}$<smiles>[R3]c1cc2c(c3c1OC(C)(C)C=C3)NC(=O)[C@]21C([R])([R])[C@H]2C(=O)N3CCC[C@H]3C[C@H]2C1(C)C</smiles>

5-Chlorosclerotiamide (51) 10-epi-sclerotiamide (52)
$B n=12$

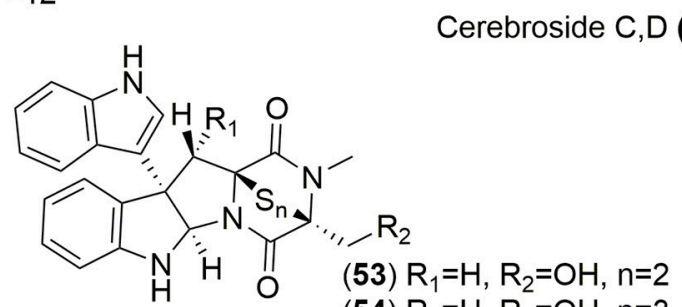

(54) $\mathrm{R}_{1}=\mathrm{H}, \mathrm{R}_{2}=\mathrm{OH}, \mathrm{n}=3$

(55) $\mathrm{R}_{1}=\mathrm{OH}, \mathrm{R}_{2}=\mathrm{OH}, \mathrm{n}=3$

(56) $\mathrm{R}_{1}=\mathrm{OH}, \mathrm{R}_{2}=\mathrm{H}, \mathrm{n}=2$

(57) $\mathrm{R}_{1}=\mathrm{OH}, \mathrm{R}_{2}=\mathrm{H}, \mathrm{n}=3$

Luteoalbusins A-B (53,54), T988A

(55), Gliocladines C-D $(56,57)$

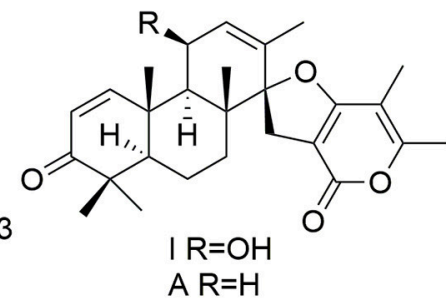

Brevione I,A (58,59)

FIGURE 1 | Structures of metabolites obtained from deep sea marine fungi. For complete chemical names, please see Supplementary Table 1.

led to the determination of its chemical structure. Compound (13) displayed weak antiproliferation activities toward K562 and promyelocytic HL-6 cell lines with $\mathrm{IC}_{50}$ values ranging between
25.8 and $44.9 \mu \mathrm{M}$ (Fredimoses et al., 2015). Xanthocillin X (14), chrysogine (15) and meleagrin (16; Figure 1) were discovered from Penicillium commune SD-118. The growth inhibition of 
compound (14) was evaluated against MCF-7, HepG2, NCIH460, HeLa, DU145, and MDA-MB- 231 cell lines with the $\mathrm{IC}_{50}$ values of $12.0,7.0,10.0,10.0,8.0$, and $8.0 \mu \mathrm{g} / \mathrm{mL}$ respectively. The cytotoxicity of compound (15) was moderate against SW1990 cell line with an $\mathrm{IC}_{50}$ value of $20.0 \mu \mathrm{g} / \mathrm{mL}$, whereas compound (16) exhibited potent cytotoxicity against DU145 cell line with an $\mathrm{IC}_{50}$ value of $5.0 \mu \mathrm{g} / \mathrm{mL}$. It also showed moderate cytotoxicity toward HepG2, NCIH460, HeLa, and MDA-MB-231 cell lines with $\mathrm{IC}_{50}$ values of $12.0,22.0,20.0$, and $11.0 \mu \mathrm{g} / \mathrm{mL}$ respectively (Shang et al., 2012a; Zhao et al., 2012).

Using a combination of traditional and high-performance liquid chromatography techniques, eremophilane type sesquiterpene (17; Figure 1) and an analog of one tautomeric form of eremofortine C (18) were isolated from the Antarctic deep-sea fungus Penicillium sp. PR19 N-. The cytotoxicity studies of compounds (17) and (18) against HL-60 cells were evaluated which gave $\mathrm{IC}_{50}$ values of $45.8,28.3 \mu \mathrm{M}$ respectively. The inhibitory concentrations of compounds (17) and (18) against A-549 cells were found to have $\mathrm{IC}_{50}$ values of $82.8,5.2 \mu \mathrm{M}$ respectively (Lin et al., 2014). Nine new $\mathrm{C}_{9}$ polyketides named aspiketolactonol (19), aspilactonols A-F (20-25; Figure 1), aspyronol (26) and epiaspinonediol (27) were isolated together with five known polyketides (S)-2-(2'-hydroxyethyl)-4-methyl$\gamma$-butyrolactone (28), dihydroaspyrone (29), aspinotriol A (30), aspinotriol B (31) and chaetoquadrin F (32) from Aspergillus sp. 16-02-1, which was collected from a deep-sea sediment at a Lau Basin hydrothermal vent in the southwest of the Pacific Ocean. NMR, mass and CD spectroscopy techniques were used to determine the chemical structure and assign the absolute configuration of these novel molecules. Compounds (19-32) exhibited significant cytotoxic activities with inhibitory rate (IR\%) values at $100 \mu \mathrm{g} / \mathrm{mL}$ between 10 and $79 \%$ against human cancer cell lines K562, HL-60, HeLa, and BGC-823 (Chen X. et al., 2014). Six metabolites, (33-38; Figure 1) were isolated from a mutated deep-sea fungal strain of Aspergillus versicolor ZBY-3. Their inhibitory activities were determined aginst K562 cells at a concentration of $100 \mu \mathrm{g} / \mathrm{mL}$ which showed inhibitory rates of $54.6,72.9,23.5,29.6,30.9$, and $51.1 \%$ respectively (Dong et al., 2014). From a deep-sea fungus Engyodontium album DFFSCS021, a new chromone engyodontiumones $\mathrm{H}$ (39) and a known polyketide (40; Figure 1) were isolated. Their cytotoxcities were determined which showed selectivity against human histiocytic lymphoma U937 cell line with the $\mathrm{IC}_{50}$ values of 4.9 and $8.8 \mu \mathrm{M}$ respectively (Yao et al., 2014).

An Antarctic deep-sea derived fungus Penicillium sp. PR19N1 was the source of compound (41; Figure 1). Its chemical structures was established using IR, HRMS as well as one and two-dimensional NMR techniques. The cytotoxicity of compound (41) was modest against HL-60 and A549 cell lines with $\mathrm{IC}_{50}$ values of 11.8 and $12.2 \mu \mathrm{M}$ respectively ( $\mathrm{Wu}$ et al., 2013). The deep-sea sediment of the South China Sea was the source of fungus Aspergillus dimorphicus SD317 from which, Wentilactone A (42) and B (43; Figure 1) were isolated (Xu et al., 2015). Further exploration of induced apoptosis of Wentilactone A (42) displayed G2/M cell cycle arrest of human lung carcinoma cells (Lv et al., 2013). Wentilactone B (43) inhibited proliferation and migration of human hepatoma SMMC-7721 cells (Zhang et al., 2013). Seven secondary metabolites including ergosterol peroxide derivative (44), ergosterol peroxide (45), (22E,24R)-5 $\alpha, 6 \alpha$ epoxy-3 $\beta$-hydroxyergosta-22-ene-7-one (46), and cerebroside AD (47-50; Figure 1) were reported by Cui and coworkers in 2013 from the deep-sea fungus Paecilomyces lilacinus ZBY-1. These compounds exhibit cytotoxic activity against K562, MCF-7, HL60 , and BGC-823 cells with $\mathrm{IC}_{50}$ of $22.3-139.0 \mu \mathrm{M}$ (Cui et al., 2013). The compounds 5-chlorosclerotiamide (51) and 10-episclerotiamide (52) were the secondary metabolites of the deepsea fungus Aspergillus westerdijkiae DFFSCS013, which showed excellent cytotoxicity against K562 cell line with IC $_{50}$ of 44 and $53 \mu \mathrm{M}$ respectively (Peng et al., 2013). Another deep-sea sediment in the South China Sea was the source of fungus Acrostalagmus luteoalbus SCSIO F457 from which metabolites luteoalbusins A-B $(53,54)$, T988A (55) and gliocladines C-D $(56,57)$ were isolated (Figure $\mathbf{1})$. The cytotoxicity of compound (53) was evaluated against SF-268 MCF-7 NCI-H460 HepG-2 cell lines, which gave $\mathrm{IC}_{50}$ values of $0.46,0.233,1.15$, and $0.91 \mu \mathrm{M}$ respectively. Similarly, the cytotoxicity of compound (54) against SF-268 MCF-7 NCI-H460 HepG-2 gave IC $_{50}$ values of 0.59, 0.25 , 1.31, 1.29 $\mu \mathrm{M}$ respectively. Compounds (55-57) were slightly less cytotoxic against SF-268, MCF-7, NCI-H460, and HepG-2 with $\mathrm{IC}_{50}$ values ranging in between 0.91 and $17,7 \mu \mathrm{M}$ respectively. The positive control cisplatin, exhibited cytotoxicity against SF268, MCF-7, NCI-H460, and HepG-2 cell lines with IC $_{50}$ values of 4.7, 3.9, 2.9, and $2.4 \mu \mathrm{M}$ respectively (Wang et al., 2012). Breviones I and A $(\mathbf{5 8}, \mathbf{5 9})$ were isolated from the deep-sea fungus Penicillium sp. in China (Figure 1). The cytotoxicity of compounds (58) and (59) were determined against MCF-7 cells lines, which gave $\mathrm{IC}_{50}$ values of 7.44 and $28.4 \mu \mathrm{M}$ respectively. The $\mathrm{IC}_{50}$ of compound (58) against A549 cells was found to be $32.5 \mu \mathrm{M}$ (cisplatin, the positive control, gave $\mathrm{IC}_{50}$ values of 8.0 and $8.9 \mu \mathrm{M}$ against these two tumor cell lines; Li et al., 2012).

\section{COMPOUNDS FROM ALGAE-ASSOCIATED FUNGI}

Marine algae-derived endophytic fungus Paecilomyces variotii EN-291 was the source of indole derivatives varioloid A (60) and varioloid B (61; Figure 2). Both compounds were cytotoxic against A549, HCT116, and HepG2 cell lines with $\mathrm{IC}_{50}$ values between 2.6 and $8.2 \mu \mathrm{g} / \mathrm{mL}$ (Zhang et al., 2016). Another marine algae-derived fungus Aspergillus ochraceus Jcma1F17 gave cinnamolide derivative (62) and a known compound insulicolide A (63) whose chemical structures are given in Figure 2. The cytotoxicity of these compounds was determined against H1975, U937, K562,-823, Molt-4,-7, A549, HeLa, HL60, and Huh-7 human cancer cell lines, which gave $\mathrm{IC}_{50}$ values between 1.95 and $6.35 \mu \mathrm{M}$ (Fang et al., 2014).

Marine red alga Lomentaria catenata was collected at Guryongpo, NamGu, PoHang in Republic of Korea. From the surface of this alga, fungus Microsporum sp. (MFS-YL) was obtained from which physcion (64) was isolated (Figure 2). Physcion (64) induced apoptosis in HeLa cells and its effect on the expressions of p53, p21, Bax, Bcl-2, caspase-9, and 
<smiles></smiles>

Varioloid A (60)

Varioloid B (61)

Compound (62)<smiles>C[C@]12CCC[C@@](C)(CO)[C@H]1[C@@H](OC(=O)c1ccc([N+](=O)[O-])cc1)C=C1C(=O)OC[C@]12O</smiles><smiles>COc1cc(O)c2c(c1)C(=O)c1cc(C)cc(O)c1C2=O</smiles>

Physcion (64)<smiles>C=CC(C)(C)c1[nH]c2ccccc2c1/C=C1\NC(=O)[C@H](C)NC1=O</smiles>

Neoechinulin A (65)

Insulicolide A (63)<smiles>CC(C)(C)O[Mg]O[Mg]</smiles>

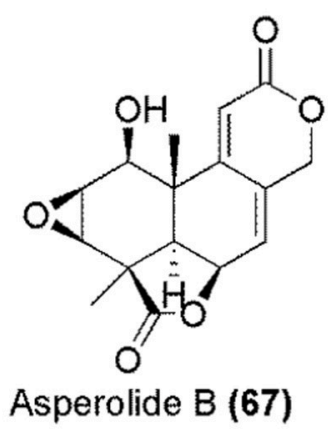<smiles></smiles>

Tetranorditerpenoid (68)

FIGURE 2 | Structures of metabolites obtained from marine algae associated fungi.

caspase- 3 proteins were investigated. The western blot analysis revealed that physcion (64) induces cell apoptosis through downregulation of $\mathrm{Bcl}-2$ expression, up-regulation of Bax expression, and activation the caspase-3 pathway. Additionally, physcion (64) also induced the formation of reactive oxygen species (ROS) in HeLa cells (Wijesekara et al., 2014). A prenylated indole alkaloid neoechinulin A (65) (Figure 2) was obtained from a marine-derived fungus, Microsporum sp. (MFS-YL), which was isolated from the surface of a marine red alga Lomentaria catenata, collected at Guryongpo, NamGu, PoHang in the Republic of Korea. Neoechinulin A (65) has shown the cytotoxic effect on human cervical carcinoma HeLa cells and its apoptosis induction in HeLa cells was investigated by the expressions of p53, p21, Bax, Bcl-2, Caspase 9, and Caspase 3 proteins. Western blot analysis revealed that neoechinulin A (65) could induce cell apoptosis through down-regulation of Bcl-2 expression, up-regulation of Bax expression and activation the caspase-3 pathway (Wijesekara et al., 2013). Marine alga, Sargassum sp. was the source of endophytic fungus Aspergillus wentii EN-48 from which asperolides A-B (66-67) together with tetranorlabdane diterpenoid derivative (68), wentilactones A (42) and $B(43)$ were isolated. The cytotoxicity of these compounds (66-68, 42, 43) was moderate against HeLa, HepG2, MCF-7, MDA-MB-231, NCI-H460, SMMC-7721 and SW1990 tumor cell lines. Wentilactone B (43) was the most potent among the tested compounds $\left(\mathrm{IC}_{50}=17 \mu \mathrm{M}\right)$ (Sun H.-F. et al., 2012).

\section{COMPOUNDS FROM MANGROVE ENDOPHYTIC FUNGI}

Using one strain many compounds (OSMAC) approach, spirobrocazines $C(\mathbf{6 9})$ and brocazine $G(70)$ were obtained from mangrove-derived fungus Penicillium brocae MA-231 (Figure 3). Their chemical structures and absolute stereochemical 
<smiles>O=C1N[C@@]2(Cc3ccccc3O2)C(=O)N/C1=C\c1ccccc1O</smiles>

Spirobrocazine C (69)

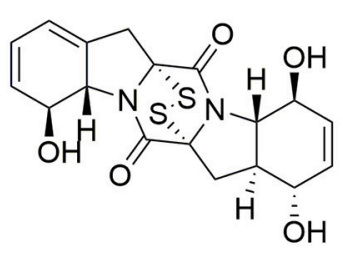

Brocazine G (70)<smiles>CCCCCCCCCc1cc(O)cc(O)c1C(=O)OCC</smiles>

2,4-Dihydroxy-6nonylbenzoate (71)<smiles>CO[C@H]1CC(=O)c2cccc3c2[C@@]12Oc1ccc(O)c4c1[C@@](O)(O4)[C@H](O)C(=O)[C@H](Cl)[C@H]3O2</smiles>

Chloropreussomerin A (72)<smiles>CO[C@@H]1C(=O)[C@@H](Cl)[C@@H](OC)c2c(O[C@]34Oc5cccc(c53)C(=O)C[C@@H]4OC)ccc(O)c21</smiles>

O;,<smiles>O=C1C[C@H](O)[C@]23Oc4ccc(O)c5c4[C@@](Oc4cccc1c42)(O3)[C@H]1CC51</smiles>

Oi',<smiles></smiles>

O',

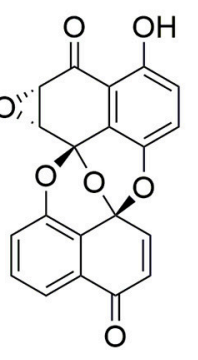

O',<smiles>Oc1ccc2c3c1C[C@H]1C[C@H](O2)[C@]32C=C[C@@H](O)c3cccc(c32)O1</smiles>

Chloropreussomerin B (73) Preussomerin K (74)<smiles>CO[C@H]1/C=C\C/C=C\[C@H](O)/C=C/C(=O)O[C@@H](C)CCC1</smiles><smiles>CO[C@H]1/C=C\C=C/C(=O)CCC(=O)O1</smiles>

7-O-methyl nigrosporolide (78)

Pestalotioprolide D (79)

Pestalotioprolides E, F $(\mathbf{8 0}, \mathbf{8 1})$<smiles>[R]C(/C=C\C=C\[C@@H](O)CCC[C@@H](C)OC(=O)/C=C/[R](=O)O)C(=O)O</smiles><smiles>C=C(C)c1c[nH]c(=O)c2c1O[C@H]1[C@H](C2=O)[C@H](/C=C/C)[C@H]2CC[C@@H](C)C[C@H]2[C@@]1(O)S</smiles>

Campyridone D (82)<smiles>C=C(O)[Te]</smiles><smiles>C/C=C/C1C(C(=O)c2c(O)c(-c3ccc(O)cc3)c[nH]c2=O)CC(C)C2CCC(C)CC12</smiles>

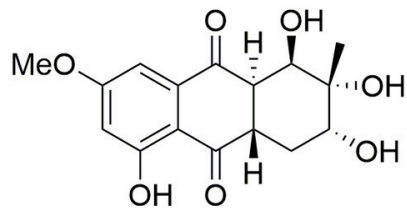

Dihydroaltersolanol C (84)<smiles>[R3]O[C@H]1C([R2])C2=C(C(=O)c3cc(OC)cc(O)c3C2=O)[C@H]([R1])[C@@]1(C)O</smiles>

A $\mathrm{R}_{1}=\mathrm{R}_{2}=\mathrm{OH}, \mathrm{R}_{3}=\mathrm{H}$ B $\mathrm{R}_{1}=\mathrm{R}_{2}=\mathrm{R}_{3}=\mathrm{H}$ $N R_{1}=R_{2}=O H, R_{3}=A c$<smiles>COc1cc(O)c2c(c1-c1c(OC)cc(O)c3c1C(=O)C1=C(C3=O)[C@@H](O)[C@@H](O)[C@](C)(O)[C@H]1O)C(=O)C1=C(C2=O)[C@H](O)[C@@H](O)[C@](C)(O)[C@H]1O</smiles>

Alterporriol E (88)
Altersolanol A, B, N (85-87)

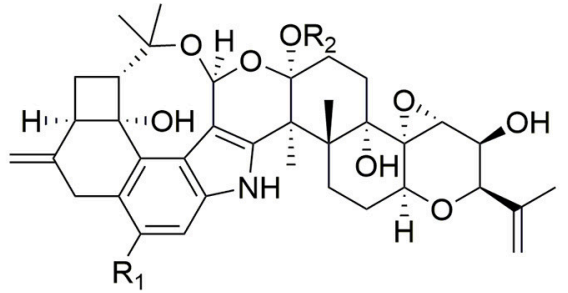

A: $\mathrm{R}_{1}=\mathrm{Cl}, \mathrm{R}_{2}=\mathrm{H}$

B: $\mathrm{R}_{1}=\mathrm{Cl}, \mathrm{R}_{2}=\mathrm{CH}_{3}$

Rhizovarins A, B (89 - 90) 


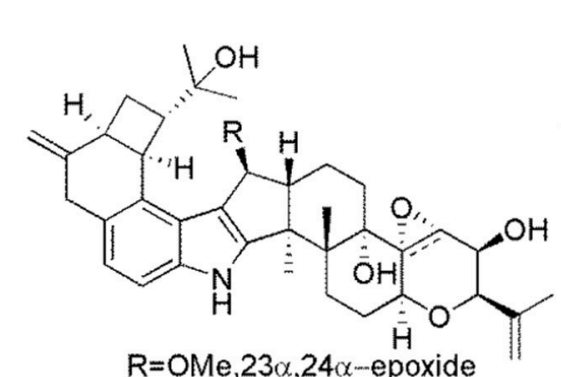

$\mathrm{R}=\mathrm{OMe}, 23 \alpha, 24 \alpha$-epoxide

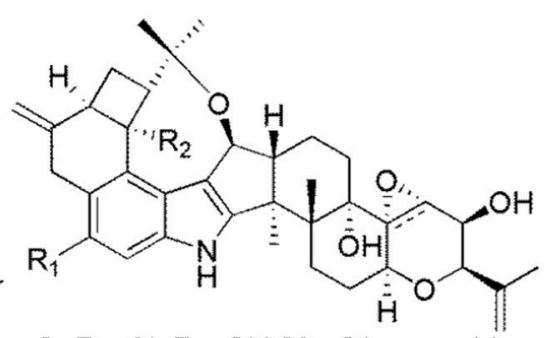

A: $\mathrm{R}_{1}=\mathrm{Cl}, \mathrm{R}_{2}=\mathrm{OH}, 23 \alpha, 24 \alpha$-epoxide

B: $R_{1}=\mathrm{Cl}, \mathrm{R}_{2}=\mathrm{H}, 23,24$-alkene

Rhizovarin E (91)

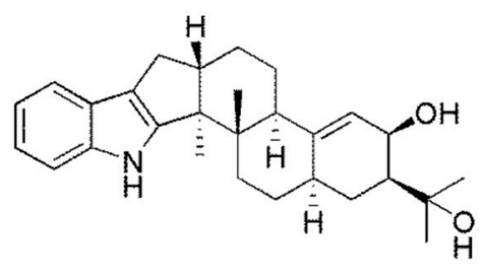

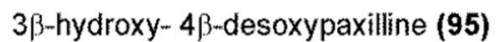<smiles>COC(=O)[C@H](C[C@@H](OC)c1c(OC)cc(O)c2c(=O)cc(C)oc12)OC</smiles>

Rhytidchromone A (97)<smiles>CCCOC(=O)c1c(O)cc(O)cc1CCCCCCCC(C)O</smiles>

Compound (101)<smiles>COc1cc(O)c2c(=O)cc(C)oc2c1[C@H]1C[C@H](OC)C(=O)O1</smiles>

Rhytidchromone B (98)<smiles>[R]OC(=O)[C@H](C[C@@H](OC)c1c(OC)cc(O)c2c(=O)cc(C)oc12)OC</smiles>

Rhytidchromones<smiles>CC(C)(C)O[AsH2]OC(C)(C)C(O)COc1ccc(CCO)cc1</smiles>

Compound (103)<smiles>CCC[C@@H]1[C@@H](C)C(=O)O[C@]12C=C(CO)CC2</smiles><smiles>C=Cc1c(C)c(O)cc2c1CC[C@H](C(=C)C)[C@]2(C)CC(C)=O</smiles>

3,4-seco-sonderianol (105)<smiles>CCCCCCCC(=O)c1c(O)cc(O)cc1CC(=O)OC</smiles>

Pestalotiopene A (107)

Cytosporone $E$ (108)<smiles>CCCCCCCC1OC(=O)c2cc(O)c(O)c(O)c21</smiles>

Dothiorelone F (109)

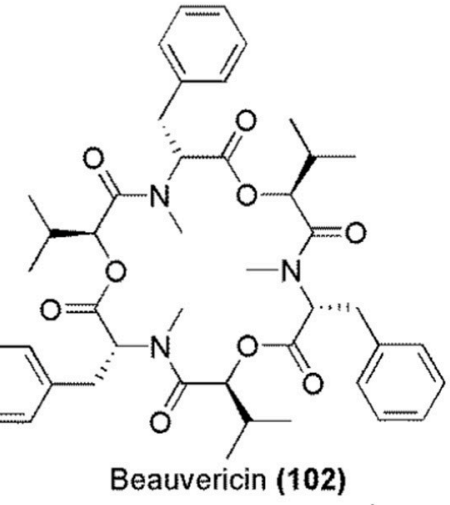<smiles>C/C=C/[C@H]1O[C@H]2O[C@H](/C=C/C)[C@@H](C(C)(C)C)OC(=O)C2=C[C@@H]1O</smiles><smiles>CCCCCCCCC(=O)c1c(O)cc(O)cc1CC(=O)OCC</smiles>

Dothiorelone $G(110)$ 


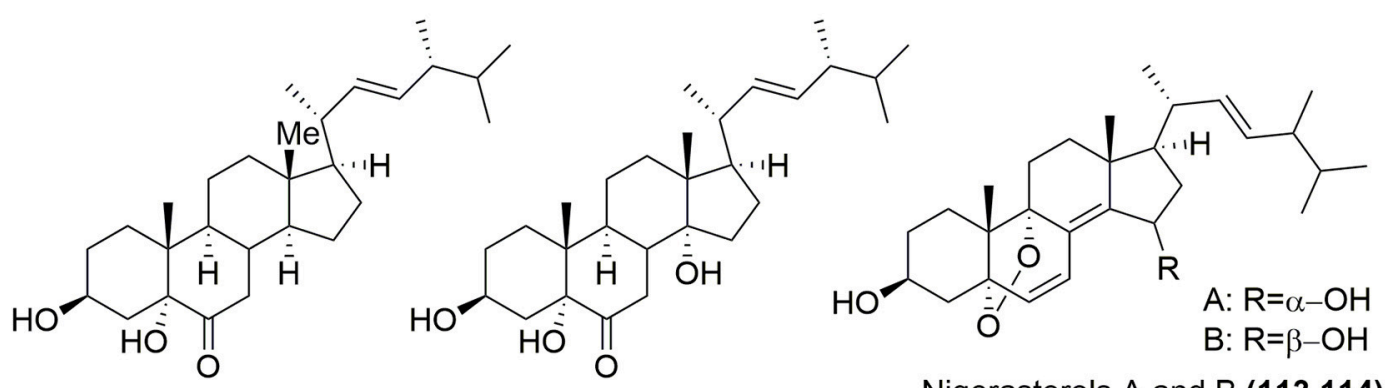

Compound (111)

Compound (112)

Nigerasterols $A$ and $B(113,114)$<smiles>COCc1cc(C)c(OC)c2c1COC2=O</smiles>

Compound (115)<smiles>CC(C)=CCc1c2occc2c(C)c2ccc(=O)oc12</smiles>

Compound (119)<smiles>[CH][C@H](COc1ccc(C[C@H](NC(=O)[C@@H]([C@@H](C)CC)N(C)C(=O)[C@H](C)NC(=O)C2CCCN2C(=O)C(C)OC(=O)C(C)N(C)C)C(=O)N[C@@H](C)C(=C)C)cc1)C(=C)C</smiles>

Pullularin E (123)
Pullularin A, C $(120,121)$<smiles>C[C@]12C=CC(=O)OC[C@H]1[C@@H](O)[C@H]1OC(=O)[C@H]3CCC[C@]312</smiles>

Botryosphaerin F (117)

A: $\mathrm{R}=\mathrm{CH}_{3}$
C: $\mathrm{R}=\mathrm{H}$<smiles>Cc1ccccc1</smiles>

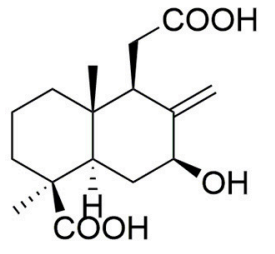

Compound (118)
Compound (116)<smiles>CC(C)=CCOc1ccccc1</smiles>

$\mathrm{R}$<smiles>CC(C)=CCOc1ccccc1</smiles>

Verticillin $D$ (122)

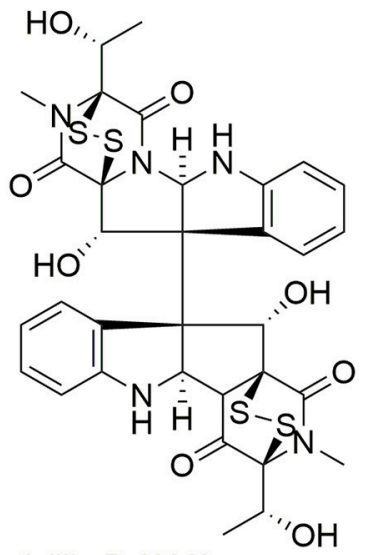

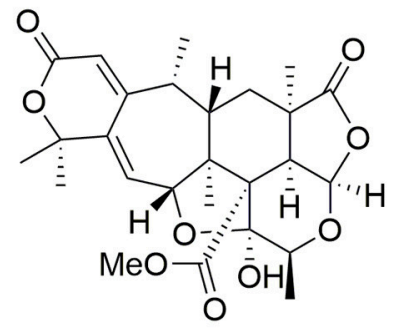

Compound (125) 


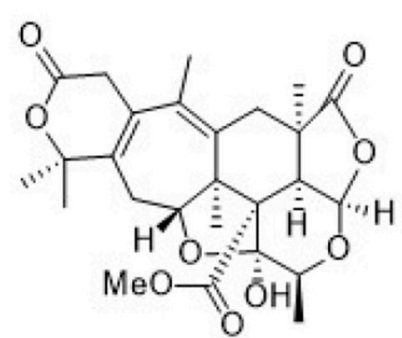

Compound (126)<smiles>COC(=O)c1cc(O)cc2oc3cc(C)c(O)cc3c(=O)c12</smiles>

Compound (129)<smiles></smiles>

Compound (127)

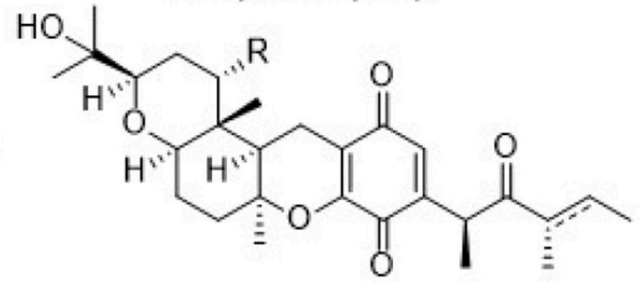

Compound (130)<smiles>O=C1N[C@@H](Cc2ccccc2)C(=O)N2C1C[C@]1(O)c3ccccc3N[C@H]21</smiles>

Ditryptophenaline (128)<smiles>Cc1ccc2c(c1)C(=O)c1c(O)ccc(O)c1C2=O</smiles>

Compound (131)

FIGURE 3 | Chemical structures of metabolites associated with marine mangrove endophytic fungi. For complete chemical names, please see Supplementary Table 1.

configurations were determined by spectroscopic analysis, computational calculations and X-ray diffraction. Spirobrocazine C (69) showed moderate activity against A2780 cells $\left(\mathrm{IC}_{50}\right.$ $59 \mu \mathrm{M})$ while compound (70) showed strong activity against A2780 and A2780 CisR cell with the $\mathrm{IC}_{50}$ values of 664 and $661 \mathrm{nM}$ respectively, which were much better than that of the positive control cisplatin, which gave $\mathrm{IC}_{50}$ values of 1.67 and $12.63 \mu \mathrm{M}$ respectively (Meng et al., 2016). 2,4-Dihydroxy-6nonylbenzoate (71; Figure 3) was isolated from a mangrove endophytic fungus, Lasiodiplodia sp. 318, which was collected from Excoecaria agallocha in Mangrove National Nature Reserve in Gaoqiao, Zhanjiang city, Guangdong Province, China. Its structure was established by spectroscopic techniques (one and two-dimensional NMR, HR-ESI-MS), and electronic CD experiment. Compound (71) exhibited cytotoxicity against MMQ and $\mathrm{GH} 3$ cell lines with the $\mathrm{IC}_{50}$ values of 5.2 and $13.0 \mu \mathrm{M}$ respectively (Huang et al., 2017). Endophytic fungus, Lasiodiplodia theobromae ZJ-HQ1 was isolated from a healthy leaf of the marine mangrove A. ilicifolius, which was collected from Zhanjiang Mangrove Nature Reserve in Guangdong Province, China. This fungus gave two new chlorinated preussomerins, chloropreussomerins $\mathrm{A}$ and $\mathrm{B}(72,73)$ together with spreussomerin $\mathrm{K}(74)$, preussomerin $\mathrm{H}$ (75), preussomerin G (76), and preussomerin F (77) as their metabolites (Figure 3). Their chemical structures were elucidated by a combination of spectroscopic techniques. The absolute configurations of (72) and (73) were determined by single-crystal X-ray diffraction techniques. Compounds (72) and (73) were the first chlorinated compounds in the preussomerins family, which showed potent in vitro cytotoxicity against $\mathrm{A} 549$ and MCF-7 human cancer cell lines with $\mathrm{IC}_{50}$ values ranging from 5.9 to $8.9 \mu \mathrm{M}$. Compounds (74-77) exhibited significant bioactivity against A549, HepG2, and MCF-7 human cancer cell lines with the $\mathrm{IC}_{50}$ values of 2.5-9.4 $\mu \mathrm{M}$ (Chen et al., 2016).

7-O-methylnigrosporolide (78), pestalotioprolides D-F (79-81) were isolated from mangrove derived endophytic fungus Pestalotiopsis microspore (Figure 3), which was obtained from fresh healthy fruits of Drepanocarpus lunatus (Fabaceae) collected from Douala, Cameroon. Co-culture of P. microspora with Streptomyces lividans resulted in roughly ten-fold enhancement in the production accumulation of compounds (80) and (81) compared to axenic fungal control. Their chemical structures were determined by the analysis of NMR and mass spectroscopy data. The cytotoxicity of these compounds (78-81) was significant against murine lymphoma cell line L5178Y, which showed $\mathrm{IC}_{50}$ values of $0.7,5.6,3.4$, and $3.9 \mu \mathrm{M}$ respectively. Compound (80) was potent against the human ovarian cancer cell line $\mathrm{A} 2780$ with an $\mathrm{IC}_{50}$ value of 1.2 $\mu \mathrm{M}$ (Liu et al., 2016). Campyridones D (82) and ilicicolin $\mathrm{H}$ (83) were isolated from Campylocarpon sp. HDN13-307 (Figure 3), which was obtained from the root of mangrove plant Sonneratia caseolaris. Their chemical structures and absolute configurations were determined on the basis of spectroscopic analysis and electronic CD results. Campyridone D (82) and ilicicolin $\mathrm{H}(\mathbf{8 3})$ were cytotoxic against HeLa cell with the $\mathrm{IC}_{50}$ values of 8.8 and $4.7 \mu \mathrm{M}$ respectively (Zhu et al., 2016).

Dihydroaltersolanol C (84), altersolanols A, B, N (85-87), and alterporriol E (88) were isolated from white bean solid culture media of the endophytic fungus, Stemphylium globuliferum, collected from the Egyptian mangrove plant Avicennia marina (Figure 3). Their structures were elucidated using one and twodimensional NMR spectroscopy as well as high-resolution mass spectroscopy (Moussa et al., 2016). Dihydroaltersolanol C (84), altersolanol A (85), B (86), and alterporriol E (88) exhibited 
toxicity against L5178Y mouse lymphoma cell line with the $\mathrm{IC}_{50}$ values of 3.4, 2.5, 3.7, and 6.9 $\mu \mathrm{M}$ (Liu Y. et al., 2015). Altersolanol $\mathrm{N}$ (87) also exhibited potent cytotoxicity against L5178Y mouse lymphoma cell line with $\mathrm{IC}_{50}$ values in the low micromolar range (Debbab et al., 2012). Altersolanol A (85) showed cytotoxic activity against 34 human cancer cell lines in vitro, with mean $\mathrm{IC}_{50}\left(\mathrm{IC}_{70}\right)$ values of $0.005 \mu \mathrm{g} / \mathrm{mL}(0.024 \mu \mathrm{g} / \mathrm{ml})$ respectively (Mishra et al., 2015). The cellular activity of altersolanol A (85) has been studied in detail, which has shown that it is a kinase inhibitor which induces cell death by apoptosis through caspase dependent pathway. Altersolanol A (85) inhibited a variety of kinases, which suggested that the kinase inhibition might be the mechanism for the cytotoxic activity (Debbab et al., 2009). Further studies revealed that its antitumor potential was linked to pro-apoptotic and anti-invasive activity that occurred through the inhibition of NF- $\kappa \mathrm{B}$ transcriptional activity (Teiten et al., 2013). Mucor irregularis QEN-189, an endophytic fungus obtained from the fresh inner tissue of the marine mangrove plant Rhizophora stylosa, collected in Hainan Island, China was the source of rhizovarins A, B, E (89-91), penitrems A, C, F (92-94), and 3 $\beta$-hydroxy- $4 \beta$-desoxypaxilline (95) whose chemical structures are shown in Figure 3. The structures of these compounds were determined by detailed spectroscopic analysis. Compounds (89-94) were cytotoxic against the human A-549 cell lines with $\mathrm{IC}_{50}$ values of $11.5,6.3,9.2,8.4,8.0,8.2$, and $4.6 \mu \mathrm{M}$, while compounds $(\mathbf{8 9}, \mathbf{9 0}, \mathbf{9 2 - 9 5})$ showed cytotoxicity against the human HL-60 cell lines with $\mathrm{IC}_{50}$ values of 9.6, $5.0,7.0,4.7,3.3$, and $2.6 \mu \mathrm{M}$ respectively. Adriamycin, a positive control, exhibited cytotoxicity with the $\mathrm{IC}_{50}$ values of 0.30 and $0.06 \mu \mathrm{M}$ against A-549 and HL-60 cell lines respectively (Gao et al., 2016b).

Endophytic fungus Pestalotiopsis clavispora isolated from the mangrove plant Rhizophora harrisonii was the source of a new polyketide derivative pestalpolyol I (96; Figure 3). The chemical structure of the new compound was determined using one and two-dimensional NMR spectroscopy, as well as by high-resolution mass spectrometry. Compound (96) displayed cytotoxicity against the mouse lymphoma cell line L5178Y activity with an $\mathrm{IC}_{50}$ value of $4.10 \mu \mathrm{M}$ (Perez et al., 2016). Four highly oxygenated chromones, rhytidchromone A, B, C, and E (97-100) were isolated from the culture broth of a mangrovederived endophytic fungus, Rhytidhysteron rufulum, which was obtained from Thai Bruguiera gymnorrhiza (Figure 3). Their structures were determined by analysis of $1 \mathrm{D}$ and $2 \mathrm{D}$ NMR spectroscopic data. The structure of rhytidchromone A (97) was further confirmed by single-crystal X-ray diffraction analysis. Compounds (97-100) displayed cytotoxicity against Kato-3 cell lines with the $\mathrm{IC}_{50}$ values ranging from 16.0 to $23.3 \mu \mathrm{M}$, while rhytidchromones A and $\mathrm{C}$ were active against MCF-7 cells with the $\mathrm{IC}_{50}$ values of 19.3 and $17.7 \mu \mathrm{M}$ respectively (Chokpaiboon et al., 2016).

Another compound ethyl-2,4-dihydroxy-6-( $8^{\prime}$ hydroxynonyl)- benzoate (101; Figure 3) was isolated from a mangrove endophytic fungus, Lasiodiplodia sp. 318\# and its complete chemical structure was elucidated by spectroscopic techniques. The compound (101) was cytotoxic against several cell lines with the $\mathrm{IC}_{50}$ values of $10.1 \mu \mathrm{M}$ (MDA-MB-435),
$12.5 \mu \mathrm{M}$ (HepG2), $11.9 \mu \mathrm{M}$ (HCT-116), $13.31 \mu \mathrm{M}$ (A549), and $39.74 \mu \mathrm{M}$ (THP1) respectively (Li J. et al., 2016). Mangrove derived endophytic fungus Fusarium sp. (No. DZ27) in the South China Sea was the source of beauvericin (102), a cyclic peptide (Figure 3), and its chemical structure was deduced by spectroscopic methods and also using the reference data from the literature. Beauvericin (102) was potent in the growth inhibition of $\mathrm{KB}$ and $\mathrm{KBv} 200$ cells with the $\mathrm{IC}_{50}$ values of 5.76 and $5.34 \mu \mathrm{M}$. Further analysis of beauvericin (102) activity was done, which showed that it induced apoptosis through the decrease of reactive oxygen species generation, loss of mitochondrial membrane potential, release of cytochrome $\mathrm{C}$, activation of Caspase- 9 and -3 , and cleavage of PARP and did not regulate Bcl-2 or Bax expression (Tao et al., 2015).

Mangrove associated endophytic fungus Penicillium sp.FJ-1 of Avicennia marina, which was collected in Fujian, China was the source of two new metabolites; compounds (103) and (104) as shown in Figure 3. Their chemical structures were determined using NMR and mass spectroscopy. The antiproliferative activity of compound (103) was weak against Tca8113 and MG-63 cells with the $\mathrm{IC}_{50}$ values of 26 and $35 \mu \mathrm{M}$ respectively. The positive control, taxol, gave the $\mathrm{IC}_{50}$ values of 46 and $10 \mathrm{nM}$ with Tca8113 and MG-63 cell lines respectively. The $\mathrm{IC}_{50}$ value of compound (104) on Tca8113 and normal liver cell line WRL-68 was 10 and $58 \mu \mathrm{M}$ respectively. Compound (104) also showed anti-tumor effect on MG-63 cells with an $\mathrm{IC}_{50}$ value of $55 \mathrm{nM}$. Compound (104) was also tested against nude mice, which showed significant inhibition of tumor growth of human osteosarcoma (Zheng et al., 2014). A known diterpenoid 3,4-seco-sonderianol (105; Figure 3) was isolated from endophytic fungus $\mathrm{J} 3$ of Ceriops tagal collected in the mangrove reserve of Dong Zhai Gang, Hainan province, China. Its structure was elucidated using spectroscopic methods including $1 \mathrm{D}$ and $2 \mathrm{D}$ NMR (HMQC, ${ }^{1} \mathrm{H}-$ ${ }^{1} \mathrm{H}$ COSY and HMBC). Compound (105) exhibited activities against K562, SGC-7901, and BEL-7402 cell lines with the $\mathrm{IC}_{50}$ values of $9.2,15.7$, and $25.4 \mu \mathrm{g} / \mathrm{mL}$ respectively. Paclitaxel was used as the positive control, which displayed the $\mathrm{IC}_{50}$ values of $5.1 \mu \mathrm{g} / \mathrm{mL}$ against $\mathrm{K} 562,1.6 \mu \mathrm{g} / \mathrm{mL}$ against SGC-7901 and $6.3 \mu \mathrm{g} / \mathrm{mL}$ against BEL-7402 cel lines respectively (Zeng et al., 2015). Waol A (106), pestalotiopene A (107), cytosporone E (108) were obtained from the endophytic fungus Acremonium strictum, isolated from the mangrove tree Rhizophora apiculata (Figure 3). The chemical structures of the isolated compounds were elucidated on the basis of comprehensive NMR and mass spectrometry analysis. Compounds (106-108) showed moderate cytotoxic activity against human cisplatin-sensitive ( $\mathrm{IC}_{50}$ values $27.1,76.2$, and $8.3 \mu \mathrm{M}$ respectively) and resistant A2780 cell lines ( $\mathrm{IC}_{50}$ values $12.6,30.1$, and $19.0 \mu \mathrm{M}$ respectively) (Hammerschmidt et al., 2014).

Mangrove endophytic fungus Dothiorella sp., which was obtained from the bark of the mangrove tree Aegiceras corniculatum at the estuary of Jiulong River, Fujian Province of China, was the source of two new polyketides, named dothiorelones F (109) and G (110) as shown in Figure 3. Their chemical structures were determined on the basis of NMR data and mass spectrometry. Dothiorelones F (109) and G (110) showed significant cytotoxicity against Raji cancer cell line with 
an $\mathrm{IC}_{50}$ value of $2 \mu \mathrm{g} / \mathrm{mL}$ ( $\mathrm{Du}$ and $\mathrm{Su}, 2014$ ). The mangrove endophytic fungus Aspergillus terreus (No. GX7-3B), which was obtained from a branch of Bruguiera gymnoihiza (Linn.) growing on the coastal salt marsh of the South China Sea was the source of compounds $(\mathbf{1 1 1}, \mathbf{1 1 2})$ and beauvericin (102) as shown in Figure 3. Their chemical structures were determined by the analysis of the spectroscopic data. The cytotoxicity of compounds (111) and (102) ranged from moderate to strong against MCF7, A549, HeLa, and $\mathrm{KB}$ cell lines with the $\mathrm{IC}_{50}$ values of 4.98 and 2.02 (MCF-7), 1.95 and 0.82 (A549), 0.68 and 1.14 (HeLa) and 1.50 and $1.10 \mu \mathrm{M}(\mathrm{KB})$ respectively. The inhibitory activity of compound (112) was weak against these tumor cell lines (Deng C. M. et al., 2013). Endophytic fungus Aspergillus niger MA-132 was isolated from mangrove plant Avicennia marina, which was the source of two sterol derivatives nigerasterols $A$ and $B(113,114)$ as shown in Figure 3. The chemical structures and absolute configurations of these compounds were determined using spectroscopic methods. Modified version of Mosher's method was used to confirm the absolute configuration of compound (113). Nigerasterols A and B $(\mathbf{1 1 3}, \mathbf{1 1 4})$, which represent the first 5,9-epidioxy-sterol compounds of marine origin were evaluated for cytotoxicity. Nigerasterol B (114) displayed potent activity against the tumor cell line HL60 with an $\mathrm{IC}_{50}$ value of $1.50 \mu \mathrm{M}$, while nigerasterol A (113) displayed stronger activity with an $\mathrm{IC}_{50}$ value of $0.30 \mu \mathrm{M}$. Both compounds (113) and (114) displayed potent activities against A549 cell line with the $\mathrm{IC}_{50}$ values of 1.82 and $5.41 \mu \mathrm{M}$ respectively (Liu et al., 2013).

A new isobenzofuranone, 4-(methoxymethyl)-7-methoxy-6methyl-1(3H)-isobenzofuranone (115; Figure 3) was isolated from the mangrove endophytic fungus Penicillium sp. ZH58, which was obtained from the South China Sea coast. Its chemical structure was determined by the analysis of spectroscopic data. Compound (115) exhibited cytotoxicity against $\mathrm{KB}$ and $\mathrm{KB}_{\mathrm{V} 200}$ cells with the $\mathrm{IC}_{50}$ values of 6 and $10 \mu \mathrm{g} / \mathrm{mL}$, respectively (Yang et al., 2013). A new xanthone derivative (116; Figure 3) was isolated from the culture of mangrove endophytic fungus, Phomopsis sp. (ZH76). Its chemical structure was determined on the basis of spectroscopic data. Compound (116) inhibited the growth of HEp-2 and HepG2 cells with the $\mathrm{IC}_{50}$ values of 9 and $16 \mu \mathrm{M}$ respectively (Huang et al., 2013). Mangrove fungus Aspergillus terreus (No. GX7-3B) led to the production of two metabolites: compound (117) and compound (118) as shown in Figure 3. The chemcial structures of these compounds were determined on the basis of spectroscopic data. Compound (117) showed inhibitory activity toward MCF-7 and HL-60 cancer cell lines with the $\mathrm{IC}_{50}$ values of 4.4 and $3.4 \mu \mathrm{M}$, respectively. The cytotoxicity of compound (118) was promising against HL-60 cell line with an $\mathrm{IC}_{50}$ value of $0.6 \mu \mathrm{M}$ (Deng C. et al., 2013). Mangrove endophytic fungus, Penicillium sp. ZH16 was obtained from the South China Sea, which produced furanocoumarin derivative (119) as shown in Figure 3. Its chemical structure was determined by the analysis of NMR and mass spectroscopic data. Compound (119) was cytotoxic against $\mathrm{KB}$ and $\mathrm{KB}_{\mathrm{V}} 200$ cells with the $\mathrm{IC}_{50}$ values 5 and $10 \mu \mathrm{g} / \mathrm{mL}$ respectively (Huang Z. et al., 2012). Endophytic fungus Bionectria ochroleuca, which was obtained from the inner leaf tissues of the plant Sonneratia caseolaris in Hainan island (China) produced pullularin A (120), pullularin C (121), verticillin D (122) and pullularins $E$ and $F$ $(123,124)$ as shown in Figure 3. Their chemical structures were established using NMR spectroscopy and high-resolution mass spectrometry. Compounds (120-124) were cytotoxic against the mouse lymphoma cells (L5178Y) with the $\mathrm{EC}_{50}$ values between 0.1 and $6.7 \mu \mathrm{g} / \mathrm{mL}$ (Ebrahim et al., 2012).

Meroterpenes (125-127) were isolated from the marine fungus Penicillium sp. 303 cultured from sea water samples obtained from Zhanjiang Mangrove National Nature Reserve in Guangdong Province, China (Figure 3). The isolated compounds are structurally related to the miniolutelide class of meroterpenoids and were identified as derivatives of miniolutelide B. Compounds (125) and (126) showed moderate cytotoxic activities against a panel of cancer cell lines including MDA-MB-435, HepG2, HCT-116 and A549 cell lines. Compound (127) showed potent cytotoxic activity with $\mathrm{IC}_{50}$ values of $7.13 \mu \mathrm{M}$ against MDA-MB-435 (Li J. et al., 2014). Ditryptophenaline (128) was isolated from mangrove endophytic fungus No·Gx-3a in the South China Sea (Figure 3). Ditryptophenaline showed strong inhibitory activity on $\mathrm{KB}$ and KBv200 cell lines with $\mathrm{LD}_{50}$ values of 8.0 and $12.0 \mu \mathrm{M}$ (Yang et al., 2013b). A marine fungus Phomopsis sp. (No. SK7RN3G1) was obtained from mangrove sediment of Shankou in Hainan, China, which led to the production of a new xanthone derivative (129) as shown in Figure 3. Its chemical structure was determined by spectroscopic methods and it was found to be cytotoxic against HEp-2 and HepG2 cells with the $\mathrm{IC}_{50}$ values of 8 and $9 \mu \mathrm{g} / \mathrm{mL}$ (Yang et al., 2013c). The endophytic fungus Nigrospora sp. MA75 was obtained from the marine semimangrove plant Pongamia pinnata that led to the production of a new quinone derivative (130; Figure 3 ) which was isolated from Nigrospora sp. MA75, an. The chemical structure of compound (130) was elucidated by detailed spectroscopic analysis and absolute configuration determination. Compound (130) showed potent inhibition growth of MCF-7, SW1990, and SMMC7721 tumor cell lines with the $\mathrm{IC}_{50}$ values of 4,5 , and $7 \mu \mathrm{g} / \mathrm{mL}$ respectively (Shang et al., 2012b). Anthracene derivative (131) was isolated from mangrove endophytic fungus No.5094 which was collected in the South China Sea as shown in Figure 3. The compound was identified on the basis of spectral analysis. Compound (131) showed strong inhibitory activity with $\mathrm{KB}$ and KBv200 cell lines having the $\mathrm{LD}_{50}$ values of 5.5 and $10.2 \mu \mathrm{M}$ respectively (Yang et al., 2013a).

\section{COMPOUNDS FROM MARINE SEDIMENT-DERIVED FUNGI}

Marine sediment-derived fungus Eutypella sp. FS46 was obtained from the South China Sea. The culture of this fungus produced a pimarane-type diterpene, scopararane I (134) as shown in Figure 4. Compound (132) showed moderate cytotoxicity against MCF-7, NCI-H460 and SF-268 cell lines with the $\mathrm{IC}_{50}$ values 83.9, 13.5, and $25.3 \mu \mathrm{g} / \mathrm{mL}$ respectively (Liu et al., 2017). Hetero-spirocyclic $\gamma$-lactams pseurotin A (133), pseurotin D (134), alkaloids fumitremorgin C (135), and 


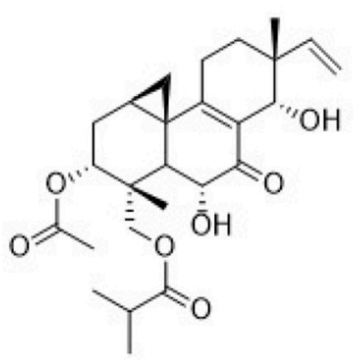

Scopararane I (132)<smiles>C[C@H]1c2nc3ccccc3c(=O)n2[C@@H]2CC3(O[C@@]12O)C(=O)Nc1ccccc13</smiles>

Tryptoquivaline T (137)<smiles>[R]C/C=C\[C@@H](O)[C@H](O)[C@H](C)C(C)C</smiles><smiles>[R]C1c2c([nH]c3cc(OC)ccc23)C(C=C(C)C)N2C(=O)C3CCCN3C(=O)C12[R]</smiles>

Fumitremorgin $\mathrm{C}(\mathbf{1 3 5})^{145 \mathrm{R}=\mathrm{OH}}$

12,13-dihydroxy Fumitremorgin C (136)

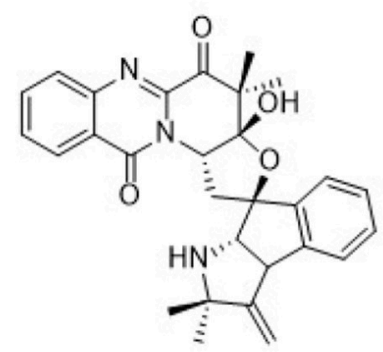

Tryptoquivaline $U$ (138)<smiles>CC(C)[C@]1(C)NC(=O)[C@H](Cc2c[nH]c3ccccc23)n2c1nc1ccccc1c2=O</smiles>

Fiscalin B (139)<smiles>CC(=NCC(C)(C)O)Nc1ccccc1C(=O)O</smiles>

Penipacid A (140)<smiles>O=C(O)c1ccccc1N/C=N/c1ccco1</smiles>

Penipacid E (141)<smiles>CC(=O)C(C)=Nc1ccccc1C(=O)O</smiles>

Compound (142)<smiles>C=C(C)CC/C=C\C1=C(COC)C(=O)OCc2cc(C)cc(O)c2O1</smiles>

Prenpenicillide (143)<smiles>COc1c(C(O)CC(C)C)ccc2c1C(=O)OCc1cc(C)cc(O)c1O2</smiles>

Penicillide (144)<smiles>C=CC1(C)C=C2C(=O)C(O)=C3C(=C1)[C@]2(C)[C@@H](C)C[C@H](O)C3(C)C</smiles>

Scopararane D (147)<smiles>CC1C[C@H](O)[C@H]2[C@H](C(=O)CCO)[C@](O)(C=C[C@]2(C)O)C1</smiles>

Decumbenone C (145)<smiles>C=CC1(C)C=C2C(=O)C(O)=C3C(C)(C)[C@H](C)CC(O)[C@]3(O)[C@@H]2CC1</smiles>

Libertellenone A (148)<smiles>CCCCC[C@H](O)c1c(O)cc2c(c1O)C(=O)c1c(cc(OC)c(Cl)c1O)C2=O</smiles>

6-O-methyl-7-chloroaveratin (146)

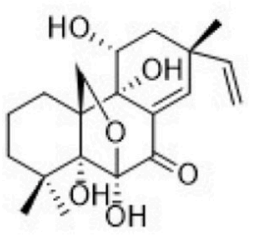

Diaporthein B (149)

FIGURE 4 | Chemical structures of metabolites obtained from marine sediment derived fungi. For complete chemical names, please see Supplementary Table 1. 
12,13-dihydroxy fumitremorgin C (136; Figure 4) were isolated from Aspergillus sp. (BRF 030) which was obtained from the sediments collected on the northeast coast of Brazil. Pseurotin A (133), pseurotin D (134), fumitremorgin C (135), and 12,13dihydroxy-fumitremorgin $\mathrm{C}$ (136) showed toxicity against HCT116 cell line with the $\mathrm{IC}_{50}$ values $72.0,85.0,15.1$, and $4.5 \mu \mathrm{M}$ (Saraiva et al., 2015). Tryptoquivaline T (137), tryptoquivaline $\mathrm{U}$ (138), and fiscalin B (139) were isolated from Neosartorya fischeri which was obtained from marine mud in the intertidal zone of Hainan Province of China (Figure 4). The bioactivity of compounds (137-139) toward apoptosis of HL-60 cells were done which showed the $\mathrm{IC}_{50}$ values of $82.3,90.0$, and $8.8 \mu \mathrm{M}$ respectively (Wu et al., 2015). Fungus Penicillium paneum SD-44 was obtained from marine sediment sample in the South China Sea which produced anthranilic acid derivatives penipacids $A$ and E (140, 141; Figure 4) together with one known analog (142). Their chemical structures were deduced using NMR and mass spectrometry analysis. Penipacids A (140) and E (141) inhibited RKO cell growth with the $\mathrm{IC}_{50}$ values of 8.4 and $9.7 \mu \mathrm{M}$ while compound (142) was cytotoxic against HeLa cell line with an $\mathrm{IC}_{50}$ value of $6.6 \mu \mathrm{M}$, which was better than the positive control fluorouracil $\left(\mathrm{IC}_{50}=25.0\right.$ and $14.5 \mu \mathrm{M}$ against $\mathrm{RKO}$ and HeLa cells lines respectively; Li et al., 2013).

Marine-derived fungus Penicillium sp. ZLN29 was obtained from the sediments collected in the Jiaozhou Bay of China from which penicillide derivative (143) and a known polyketide compound (144) were isolated (Figure 4). Compounds (143) and (144) showed weak cytotoxicity against HepG2 cell line with the $\mathrm{IC}_{50}$ values of 9.9 and $9.7 \mu \mathrm{M}$ respectively (Gao et al., 2013a). The marine fungus Aspergillus sulphureus KMM 4640 was obtained from marine sediments which produced a new decalin derivative decumbenone $C$ (145) as shown in Figure 4. Decumbenone C (145) was cytotoxic against SK-MEL-5 human melanoma cells with an $\mathrm{IC}_{50}$ value of $0.9 \mu \mathrm{M}$ (Zhuravleva et al., 2012). Marine-derived fungus Aspergillus sp. SCSIO F063 was obtained from a marine sediment sample, collected in the South China Sea which produced chloroaveratin derivative (146) as shown in Figure 4. Chemical structure determination was done by spectroscopic analyses that included mass spectrometry and NMR. Compound (146) showed inhibitory activity against three human tumor cell lines; SF-268, MCF-7, and NCI-H460 with the $\mathrm{IC}_{50}$ values of $7.1,6.6$, and $7.4 \mu \mathrm{M}$ respectively (Huang $\mathrm{H}$. et al., 2012).

Marine-derived fungus Eutypella scoparia FS26 that had been obtained from the sediment collected in the South China Sea produced scopararane D (147), libertellenone A (148) and diaporthein B (149) whose structures are depicted in Figure 4. All isolated compounds were assessed for their antiproliferative activity using a cytotoxicity (MTT) assay against three different human cancer cell lines: MCF-7 (breast), NCIH460 (lung), and SF-268 (brain). Compound (147) showed only mild antiproliferative activity with the $\mathrm{IC}_{50}$ values between 25.6 and $46.0 \mu \mathrm{M}$, whereas, libertellenone A (148) and diaporthein B (149), revealed potent antiproliferative activities with $\mathrm{IC}_{50}$ values ranging from 4.4 to $20.0 \mu \mathrm{M}$, compared to cisplatin $\left(\mathrm{IC}_{50}=\right.$ 1.5-9.2 $\mu \mathrm{M}$ ) (Sun L. et al., 2012).

\section{COMPOUNDS FROM SPONGE ASSOCIATED FUNGI}

Fungus Arthrinium arundinis ZSDS1-F3 was collected from sponge Phakellia fusca in Xisha Islands of China which led to the isolation of metabolites cytochalasin $\mathrm{K}(\mathbf{1 5 0})$ and compound (151) as shown in Figure 5. Compounds (150) and (151) showed cytotoxicity against K562, A549, Huh-7, H1975, HL60, HeLa, and MOLT- 4 cell lines with the $\mathrm{IC}_{50}$ values ranging between 1.1 and $47.4 \mu \mathrm{M}$. Compound (150) showed cytotoxicity against K562, A549, Huh-7, H1975, MCF-7, U937, BGC823, HL60, HeLa, and MOLT-4 cell lines, with $\mathrm{IC}_{50}$ values of $10.5,13.7,10.9,19.1$, $11.1,47.4$, and $11.8 \mu \mathrm{M}$ respectively while compound (151) was cytotoxic against K562, A549, Huh-7, H1975, MCF-7, U937, BGC823, HL60, HeLa MOLT-4 cell lines with IC $_{50}$ values of 6.2, $1.1,>50,14.2,18.5,3.4,18.8,6.2,3.2$, and $4.1 \mu \mathrm{M}$ respectively. The positive control trichostatin A was cytotoxic to the same cell lines with the $\mathrm{IC}_{50}$ values of $0.24,0.05,0.09,0.10,0.08,0.06$, $0.09,0.09,0.11$, and $0.03 \mu \mathrm{M}$ respectively (Wang et al., 2015). Coral-derived fungus Neosartorya laciniosa (KUFC 7896) which was collected from the coastal forest soil at Samaersarn island, Chonburi Province, Thailand was the source of aszonapyrone A (152), 13-oxofumitremorgin B (153), sartorypyrone A (154) and sartorypyrone B (155) as shown in Figure 5. The chemical structures of the new compounds were determined on the basis of one and two-dimensional NMR spectral analysis as well as HRESIMS. Aszonapyrone A (152), 13-oxofumitremorgin B (153), sartorypyrone A (154) and sartorypyrone B (155) were evaluated for their ability to inhibit the growth of MCF-7, NCI-H460, and A375-C5 cell lines. The cytotoxicity results displayed that, among the meroditerpenes tested, aszonapyrone A (152) was the most potent compound showing strong growth inhibitory activity with $\mathrm{GI}_{50}=13.6,11.6$ and $10.2 \mu \mathrm{M}$ for MCF- 7, NCIH460 and A375-C5 cell lines respectively. Sartorypyrone B (155) was also potent in growth inhibition, however, it was less active than aszonapyrone $\mathrm{A}(\mathbf{1 5 4})$ having the $\mathrm{GI}_{50}$ values $17.8,20.5$, and $25.0 \mu \mathrm{M}$ for MCF-7, NCI-H460 and A375- C5 cell lines respectively. Another compound 13-oxofumitremorgin B (153) exhibited only weak inhibitory activity against all the three cell lines $\left(\mathrm{GI}_{50}=115.0,123.3\right.$, and $68.6 \mu \mathrm{M}$ for MCF-7, NCIH460 and A375-C5 cell lines respectively; Eamvijarn et al., 2013).

The marine-derived fungus Aspergillus sp., which was obtained from the sponge Xestospongia testudinaria, was collected from the South China Sea that gave two phenolic bisabolane sesquiterpenoid dimers, disydonols A and C (156, 157) as shown in Figure 5. Their chemical structures were determined on the basis of spectroscopic analysis. Compound (156) exhibited in vitro moderate cytotoxicity toward HepG2 and Caski human tumor cell lines with the $\mathrm{IC}_{50}$ values of 9.31 and $12.40 \mu \mathrm{g} / \mathrm{mL}$ respectively. Compound (157) also displayed selectivity against HepG-2 and Caski human tumor cell lines with the $\mathrm{IC}_{50}$ values of 2.91 and $10.20 \mu \mathrm{g} / \mathrm{mL}$ respectively (Sun L.-L. et al., 2012). A new polyacetylene, xestospongiamide (158) was obtained from the Red Sea sponge, Xestospongia sp. which was collected from deep waters of 


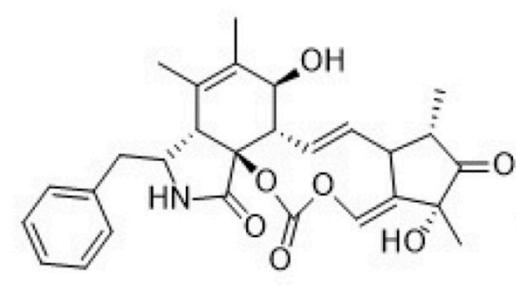

Cytochalasin K (150)

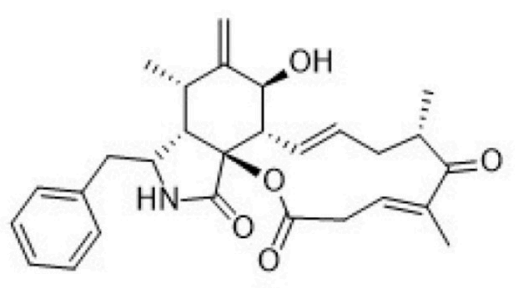

10-phenyl-[12]-cytochalasin Z16 (151)<smiles>CC(=O)O[C@H]1CC[C@@]2(C)[C@H](CC[C@@H]3[C@@H](Cc4c(O)cc(C)oc4=O)C(=O)CC[C@H]32)[C@@H]1C</smiles>

Aszonapyrone A (152)<smiles>COc1ccc2c3c(n(CC=C(C)C)c2c1)[C@@H](C=C(C)C)N1C(=O)[C@@H]2CCCN2C(=O)[C@]1(O)C3=O</smiles>

13-oxofumitremorgin B (153)<smiles>C=C1CCC(O[C@H](C)OC(C)(C)C)C(C)(C)[C@@H]1CC/C(C)=C/CC/C(C)=C/Cc1c(O)cc(C)oc1=O</smiles><smiles>CC(C)CCC[C@@](C)(O)c1ccc(COc2cc(CO)ccc2[C@](C)(O)CCCC(C)C)cc1O</smiles>

Disydonol A (156)<smiles>CC(C)CCCC(C)(C)c1ccc(Cc2cc([C@](C)(O)CCCC(C)C)c(O)cc2CO)cc1O</smiles>

Disydonol C (157)<smiles>NC(CCl)NC(=O)CCCC#CC=CCCCC#CC=CC=[W]</smiles>

Xestospongiamide (158)<smiles>COc1ccc(N2C(=O)c3c(cc(OCC=C(C)CCC=C(C)C)c(C)c3OC)[C@H]2C)c(OCC=C(C)C)c1</smiles>

Mariline A1 (159)<smiles>COc1ccc(N2C(=O)c3c(cc(OCC=C(C)CCC=C(C)C)c(C)c3OC)C2C)c(OCC=C(C)C)c1</smiles>

Mariline A2 (160)

FIGURE 5 | Chemical structures of metabolites obtained from marine sponge associated fungi.

Sharm Obhur, Jeddah, Saudi Arabia (Figure 5). Compound (158) showed antitumor effect against both Ehrlich ascites carcinoma and lymphocytic leukemia ( $\mathrm{LD}_{50} 5.0 \mu \mathrm{M}$ each) (Ayyad et al., 2015).
A marine-derived fungus of the genus Stachylidium was isolated from the sponge Callyspongia cf. C. flammea. Chemical investigation of the bioactive fungal extract led to the isolation of the novel phthalimidine derivatives 
marilines A1 and A2 (159, 160) whose chemical structures are shown in Figure 5. The absolute configurations of the enantiomeric compounds (159) and (160) were assigned using a combination of experimental circular dichroism (CD) investigation and quantum chemical CD calculations. The skeleton of marilines is unusual and its biosynthesis was suggested to require uncommon biochemical reactions in fungal secondary metabolism. Both enantiomers, marilines A1 (159) and A2 (160) inhibited human leukocyte elastase (HLE) with an $\mathrm{IC}_{50}$ value of $0.86 \mu \mathrm{M}$ (Almeida et al., 2012).

\section{COMPOUNDS FROM OTHER MARINE DERIVED FUNGUS}

Aspergillus versicolor Y31-2, which was obtained from seawater samples in the Indian Ocean, gave a quinolinone derivative (161) as shown in Figure 6. Compound (161) was cytotoxic against MCF-7 and SMMC-7721 cell lines with the $\mathrm{IC}_{50}$ values of 16.6 and $18.2 \mu \mathrm{mol} / \mathrm{L}$ (Li P. et al., 2016). Fermented products of marine fungus Penicillium sclerotiorum M-22 which was isolated from a rotten leaf sample collected on the west coast of Haikou, Hainan province, China gave two azaphilonidal derivatives penicilazaphilones B (162) and C (163) as shown in Figure 6. Cytotoxicity studies revealed that penicilazaphilones B (162) and C (163) were selective against melanoma cells B16 and human gastric cancer cells SGC-7901 with the $\mathrm{IC}_{50}$ values of $0.29,0.44$ and $0.06,0.72 \mu \mathrm{M}$ respectively. The control experiments with normal mammary epithelial cells M10 at the same concentration did not show significant toxicity (Zhou et al., 2016). A furan derivative (164) was isolated from marine-derived fungus Penicillium chrysogenum HGQ6 which was obtained from Lianyungang sea mud sample (Figure 6). The compound (164) was active against $\mathrm{BGC} 823$ cell line with an $\mathrm{IC}_{50}$ value of $0.19 \mathrm{mg} / \mathrm{mL}$, which was lower than that of adriamycin with an $\mathrm{IC}_{50}$ value of $0.06 \mathrm{mg} / \mathrm{mL}$ (Guo et al., 2016). A mutant from diethyl sulfate (DES) mutagenesis of a marine-derived fungus Penicillium purpurogenum G59 produced epiremisporine B (165), epiremisporine B1 (166) and isoconiochaetone C (167) as shown in Figure 6. Epiremisporine B (165) exhibited cytotoxicity against $\mathrm{K} 562$, HL-60, with the $\mathrm{IC}_{50}$ values of 69.0 and $62.9 \mu \mathrm{g} / \mathrm{mL}$. Similarly epiremisporine B1 (166) exhibited cytotoxicity against K562, HL-60 cell lines with the $\mathrm{IC}_{50}$ values of 53.1 and $54.7 \mu \mathrm{g} / \mathrm{mL}$ respectively while the percent inhibition rate for isoconiochaetone $C$ (167) were 20.4 and 26.0 at 100 $\mu \mathrm{g} / \mathrm{mL}$ against $\mathrm{K} 562$ and HL-60 cell lines respectively (Xia et al., 2015). Penicitrinine A (168) a novel alkaloid with a unique spiro skeleton was isolated from a marine-derived fungus Penicillium citrinum (Figure 6). Penicitrinine A (168) showed toxicity against A-375, SPC-A1, and HGC-27 cancer cell lines with $\mathrm{IC}_{50}$ values of $20.1,28.6$ and $29.4 \mu \mathrm{M}$ respectively. Morphological evaluation, apoptosis rate analysis, Western blot and real-time quantitative PCR (RT-qPCR) results showed that penicitrinine A could significantly induce A-375 cell apoptosis by decreasing the expression of $\mathrm{Bcl}-2$ and increasing the expression of Bax. Additionally, anti-metastatic effects of penicitrinine A in
A-375 cells by wound healing assay, trans-well assay, Western blot and RT-qPCR were also investigated. These results showed penicitrinine A significantly suppressed metastatic activity of A375 cells by regulating the expression of MMP-9 and its specific inhibitor TIMP-1 (Liu Q. Y. et al., 2015).

Aspergillus sp. was found in the gut of a marine isopod Ligia oceanica, which was collected in the seaside of Dinghai in Zhoushan, Zhejiang Province of China, that produced aspochalasin V (169; Figure 6). Apochalasin V (169) showed moderate activity against PC3 and HCT116 cell line with the $\mathrm{IC}_{50}$ values of 30.4 and $39.2 \mu \mathrm{M}$ respectively (Liu et al., 2014). Fungus Aspergillus terreus SCSGAF0162 was obtained from the tissue of gorgonian Echinogorgia aurantiaca collected in Sanya, Hainan Province, China which produced a cytotoxic and antiviral cyclic tetrapeptide asperterrestide A (170) as shown in Figure 6. Compound (170) was cytotoxic to human carcinoma U937 and MOLT4 cell lines with the $\mathrm{IC}_{50}$ values of 6.4 and $6.2 \mu \mathrm{M}$ respectively ( $\mathrm{He}$ et al., 2013). Aculeatusquinones B and $\mathrm{D}(\mathbf{1 7 1}, \mathbf{1 7 2})$ were produced from marine-derived fungus Aspergillus aculeatus (Figure 6). The chemical structures of these compounds were determined by spectroscopic methods. Compounds (171) and (172) were cytotoxic to HL-60, K562, and A-549 cell lines with the $\mathrm{IC}_{50}$ values in the range of $5.4-6.1 \mu \mathrm{M}$ (Chen et al., 2013).

Diorcinol D (173) and diorcinol E (174) (Figure 6) were produced from the marine-derived fungus Aspergillus versicolor. Their chemical structures were determined using spectroscopic analysis. Compound (173) was moderately cytotoxic against $\mathrm{HeLa}$ and $\mathrm{K} 562$ cell lines with the $\mathrm{IC}_{50}$ values of 31.5 and $48.9 \mu \mathrm{M}$ respectively while compound (174) showed cytotoxicity against only HeLa cell line with the $\mathrm{IC}_{50}$ value $36.5 \mu \mathrm{M}$ (Gao et al., 2013b). A new pyridinone, chaunolidone A (175; Figure 6) was isolated from marine-derived fungus Chaunopycnis sp. (CMBMF028) which was obtained from the inner tissue of a pulmonate false limpet Siphonaria sp. that was collected from rock surfaces in the intertidal zone of Moora Park, Shorncliffe, Queensland, Australia. Chaunolidone A (175) was found to be a selective and potent inhibitor of human non-small cell lung carcinoma cell NCI-H460 with the $\mathrm{IC}_{50}$ value $0.09 \mu \mathrm{M}$ (Shang et al., 2015).

Penicimutalidine (176) and a known compound oxaphenalenone (177; Figure 6) were isolated from a fungal mutant generated through the diethyl sulfate (DES) mutagenesis of marine-derived Penicillium purpurogenum G59. The $\mathrm{IC}_{50}$ values for cytotoxicity of (176) and (177) on HL-60 cells under the same conditions were determined to be $95.2 \mu \mathrm{g} /$ $\mathrm{mL}(313.2 \mu \mathrm{M})$ and $14.0 \mu \mathrm{g} / \mathrm{mL}(56.9 \mu \mathrm{M})$. Compounds (176) and (177) also weakly inhibited the K562 cells with inhibition rate (IR) \% values of 20.8 and $28.1 \%$ at $100 \mu \mathrm{g} / \mathrm{mL}$ (328.9 $\mu \mathrm{M}$ for 176 and $406.5 \mu \mathrm{M}$ for 177). The positive control 5-fluorouracil inhibited K562 cells with an IR\% of $40.3 \%$ at $100 \mu \mathrm{g} / \mathrm{mL}(796.2 \mu \mathrm{M})$ (Li C.-W. et al., 2016). A novel cyclic dipeptide, named penicimutide (178) was produced from a neomycin-resistant mutant of the marinederived fungus Penicillium purpurogenum G59 (Figure 6). Penicimutide (178) was selective against the HeLa cells with an inhibition rate (IR\%) of $39.4 \%$ at $100 \mu \mathrm{g} / \mathrm{mL}$ which was similar to that of the positive control 5-fluorouracil (IR\% 
<smiles>COc1c(-c2cccc(O)c2)c2ccccc2[nH]c1=O</smiles>

Compound (161)<smiles>O=Cc1ccc(CO)o1</smiles>

5-hydroxymethyl-2-furancarboxaldehyde (164)<smiles>CO[C@H]1CCc2oc3cc(C)cc(O)c3c(=O)c21</smiles>

Isoconiochaetone C (167)<smiles>CCC(C)[C@H](NC(=O)[C@H](C)NC(=O)c1ccccc1NC(=O)[C@@H](C(O)c1ccccc1)N(C)C(=O)[C@H](C)CC)C(=O)NC(C)C</smiles>

Asperterrestide A (170)<smiles>CCC(C)C(O)C(C)(O)C=CC1=CC2=CC(=O)[C@](C)(O)C(O)C2CO1</smiles>

Penicilazaphilone B (162)<smiles>[Y6]C1(O)C(=O)C(Cl)=C2C=C(/C=C/C(O)(O)C(C)(O)C(C)(O)CC)OCC2[C@H]1O</smiles>

Penicilazaphilone C (163)<smiles>COC(=O)C1C(O)(C(=O)OC)OC2(C(=O)OC)c3c(oc4cc(C)cc(O)c4c3=O)C3c4c(oc5cc(C)cc(O)c5c4=O)CCC312</smiles>

Compound (165)<smiles></smiles>

Epiremisporine B1 (166)<smiles>CCCCCCC(C)/C(O)=C1\C(=O)N(C)C2Oc3cc(O)c(C)c4c3C(O)(OC(C)[C@H]4C)C12</smiles>

Penicitrinine A (168)

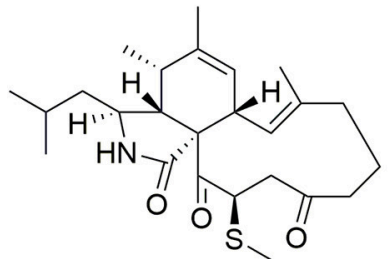

Aspochalasin V (169)<smiles>COC1(C)C(=O)C(O)=C(C)C(=O)[C@H]1Oc1cc(C)cc(O)c1C</smiles>

Aculeatusquinone $B$ (171)<smiles>COC1(OC)C(=O)C(O)=C(C)C(=O)C12Oc1c(C)c(O)cc(C)c1C2=O</smiles>

Aculeatusquinone $D$ (172)

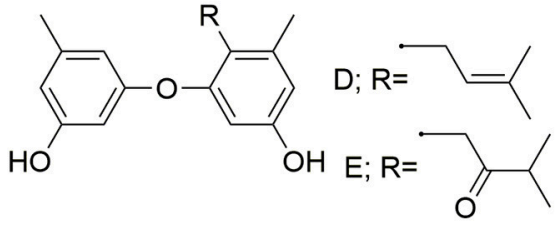

Diorcinol D,E $(173,174)$<smiles>Cc1cc(O)c2c3c(c(O)cc(O)c13)COC2=O</smiles>

Oxaphenalenone (177)<smiles>C=C(C)CC1NC(=O)C2CCCN2C1=O</smiles>

penicimutide (178)<smiles>CC1Oc2c(-c3ccc(O)cc3)c[nH]c(=O)c2C2C[C@H](C)C(O)[C@H](C)C[C@@H]12</smiles>

Chaunolidone A (175)<smiles>COC(=O)C(O)C[C@@H](C(=O)OC)[C@H]1Cc2c(oc3cc(C)cc(O)c3c2=O)S1</smiles>

Oxalicumone A (179) 
<smiles>COc1ccccc1N1CCN(C(=O)c2cn(C)c3ccccc23)CC1</smiles>

Compound (180)<smiles>COC(=O)C1c2c(oc3cc(CO)cc(O)c3c2=O)C=CC1O</smiles>

AGI-B4 (181)<smiles>CC1(C)CCC2=C3C(=O)C(C)(C)C[C@H]3C(O)[C@H](O)[C@H]2C1</smiles>

Chondrosterin J (182)

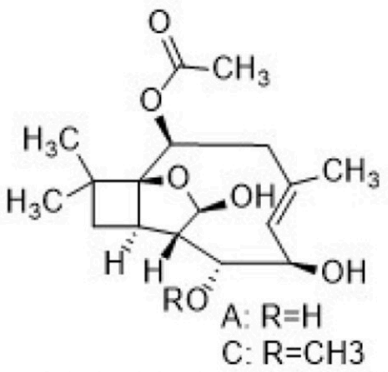

(+)-6-O-demethylpestalotiopsin $A$ and $C(183,184)$<smiles>COc1ccc2cc(NC(=O)C3=NO[C@H]4[C@@H](O)C=C[C@H](Cl)[C@@]4(O)C3)c(=O)oc2c1OC</smiles>

Trichodermamide B (188)<smiles>Cc1cc(O)cc(O)c1C(=O)c1c2c3c(c(O)cc(C)c3oc1=O)C(=O)c1c(O)cc(O)cc1-2</smiles>
Aspergiolide A (192)<smiles>O=C1CCC(O)c2c(O)cccc21</smiles>

Isosclerone (193)<smiles>COC(=O)CC(O)(C(=O)OC)C1Cc2c(oc3cc(C)cc(O)c3c2=O)S1</smiles>

Oxalicumone E (194)

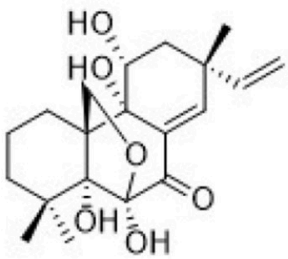

\section{Compound (185)}

Compound (186)

Diaporthin B (187)

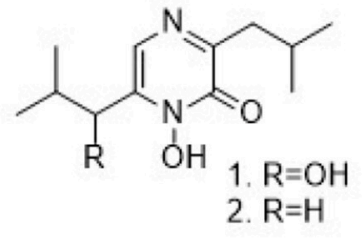

1. Neohydroxyaspergillic (190)

2. neoaspergillic acid (191)<smiles>Cc1cc(O)c2c(=O)c3c(oc2c1)CCC3=O</smiles>

Oxalicumone A (195)<smiles>NC(=O)CC[C@@H]1NC(=O)c2ccccc2-n2c1nc1ccccc1c2=O</smiles>

Auranomide C (199)

FIGURE 6 | Chemical structures of metabolites isolated from other marine derived fungi. For complete chemical names, please see Supplementary Table 1. 
of $41.4 \%$ at $100 \mu \mathrm{g} / \mathrm{mL}$ against HeLa cells) (Wang et al., 2016).

Marine-derived fungus Penicillium oxalicum SCSGAF 0023, which was isolated from the South China Sea gorgonian Muricella flexuosa, produced oxalicumone A (179; (Figure 6). The compound (179) was cytotoxic against A375 and SW-620 cell lines with $\mathrm{IC}_{50}$ values of 11.7 and $22.6 \mu \mathrm{M}$ (Sun et al., 2013). Compound (180; Figure 6) was isolated from the fungal strain Aspergillus sydowii SCSIO 00305 which was collected from a healthy tissue of Verrucella umbraculum. The compound (180) showed significant cytotoxicity against A375 cell lines with the IC $_{50}$ value of $5.7 \mu \mathrm{M}$ (He et al., 2012). A cytotoxic compound AGI-B4 (181; Figure 6) was obtained from the culture of a marine-derived fungus Neosartorya fischeri strain 1008F1. The chemical structure of the isolated compound was elucidated on the basis of spectroscopic data. Compound (181) showed toxicity aginst human gastric cancer cell line SGC-7901 with an $\mathrm{IC}_{50}$ value of $0.29 \mu \mathrm{M}$ and against hepatic cancer cells BEL-7404 with an IC $_{50}$ value of $0.31 \mu \mathrm{M}$ (Tan et al., 2012). Fungus Chondrostereum sp. which was collected from soft coral Sarcophyton tortuosum in Hainan Sanya National Coral Reef Reserve, China produced chondrosterin J (182; Figure 6). The chemical structure of the compound was determined using NMR, mass spectrometry and single crystal X-ray diffraction techniques. The compound (182) was cytotoxic against human nasopharyngeal cancer cell lines CNE-1 and 2 with the inhibitory concentration $\left(\mathrm{IC}_{50}\right)$ values of 1.32 and $0.56 \mu \mathrm{M}$ respectively (Li H.-J. et al., 2014). Fungus Ascotricha sp. ZJ-M-5 was obtained from a mud sample in Fenghua, China which produced compound (183) and (+)-6-Odemethylpestalotiopsin C (184; Figure 6). Compounds (183) and (184) were cytotoxic against HL-60 and K562 with the $\mathrm{IC}_{50}$ values 6.9 and $12.3 \mu \mathrm{M}$ respectively (Wang W.-J. et al., 2014).

Fungal strain HS-1 was isolated from the sea cucumber Apostichopus japonicas that gave two pimarane diterpenoids $(185,186)$ and a known compound diaporthin B (187) as shown in (Figure 6). Their chemical structures and absolute configurations were determined using NMR and $\mathrm{CD}$ experiments. Compounds (185-187) were effective in growth inhibition of $\mathrm{KB}$ and $\mathrm{KBv} 200$ cell lines with the $\mathrm{IC}_{50}$ values of $3.51,2.34 \mu \mathrm{g} / \mathrm{mL}, 20.74,14.47 \mu \mathrm{g} / \mathrm{mL}$, and $3.86,6.52 \mu \mathrm{g} / \mathrm{mL}$ respectively (Xia et al., 2012).

The trichodermamides are modified dipeptides isolated from a wide variety of fungi, including Trichoderma virens. Previous studies have reported that trichodermamide B initiated cytotoxicity in HCT-116 colorectal cancer cells. In the present study trichodermamide $\mathrm{B}$ (188; Figure 6) showed an $\mathrm{IC}_{50}$ value of $3.1 \mu \mathrm{M}$ in HeLa cell line. Compound (189) caused S-phase accumulation and cell death in HeLa cells, suggesting response to DNA double strand breaks (Jans et al., 2017). Chromosulfine (189; Figure 6), a novel cyclopentachromone sulfide, was isolated from a neomycin-resistant mutant of the marine-derived fungus, Penicillium purpurogenum G59. Its structure, including stereochemistry, was determined using spectroscopic methods using NMR, electronic CD (ECD) analysis and Mosher's method. The compound (189) showed toxicity against K562, HL-60, BGC-823, HeLa, and MCF-7 cell lines with IC $_{50}$ values of 60.8 , 16.7, 73.8, 75.4, and 59.2 $\mu \mathrm{M}$ (Yi et al., 2016).
Neohydroxyaspergillic (190) and neoaspergillic acid (191) (Figure 6) were isolated from the marine-derived fungus (strain CF07002) of the genus Aspergillus. Their structures were determined by the interpretation of NMR spectroscopic data which were corroborated by subsequent synthesis. Compound (191) exhibited toxicity against Jurkat, K562, U937, and Raji cell lines with the $\mathrm{IC}_{50}$ values of $31.6,50.1,42.6$, and $54.9 \mu \mathrm{M}$ respectively. Compound (190) was poorly active against Jurkat cell lines with an $\mathrm{IC}_{50}$ value of $60.2 \mu \mathrm{M}$ (Cardoso-Martinez et al., 2015). Aspergillus glaucus was obtained from the marine sediment in Fujian province of the People's Republic of China which gave a novel anthraquionone derivative aspergiolide A (192). The active components of this fungus were isolated which resulted in the identification of a novel naphtho[1,2,3de]chromene-2,7-dione skeleton. Compound (192) acts by topoisomerase II inhibition similar to adriamycin activity. Further experiments with BEL-7402 cells showed that (192) reduced cancer growth via a caspase dependent pathway (Wang Y. et al., 2014). Marine-derived fungus, Aspergillus fumigatus was isolated from marine green algae in Seosaeng-myeon, Ulsan in the Republic of Korea which produced isosclerone (193) as shown in Figure 6. It showed cytotoxicity toward MCF7 human breast cancer cells with the $\mathrm{IC}_{50}$ value $63 \mu \mathrm{M}$ after $24 \mathrm{~h}$ incubation. Further experiments showed that compound (193) inhibited the protein and gene expressions of MMP2,-9 in MCF-7 human breast cancer cells by altering MAPK signaling pathway (Li Y.-X. et al., 2014). Marine gorgonianassociated fungus Penicillium oxalicum SCSGAF 0023 produced oxalicumone E (194) and oxalicumone A (195; Figure 6). The chemical structures of these compounds were determined by spectroscopic analysis. Compounds (194) and (195) exhibited cytotoxicity against eight cell lines (H1975, U937, K562, BGC823, MOLT-4, MCF-7, HL60, and Huh-7) with the IC $_{50}$ values of $<10 \mu \mathrm{M}$ respectively (Bao et al., 2014). Deoxybostrycin (196) is an anthraquinone compound which was obtained from the marine mangrove fungus Nigrospora sp. No. 1403 as shown in Figure 6. The in vitro cytotoxicity of deoxybostrycin against MDA-MB-435, HepG2, and HCT-116 cancer cell lines were determined with the $\mathrm{IC}_{50}$ values of $3.1,29.9$, and $5.6 \mu \mathrm{M}$ respectively (Chen et al., 2012). Three new alkaloids auranomides $A$ and B $(197,198)$ and auranomide C (201) were isolated from the marine-derived fungus Penicillium aurantiogriseum (Figure 6). The chemical structures of compounds (197-199) were elucidated by using spectroscopic methods such as IR, high-resolution mass spectroscopy and two-dimensional NMR spectroscopy. Auranomides A-C (197-199) exhibited moderate cytotoxic activity against K562, ACHN, HEPG2, and A549 cell lines. Auranomide B (199) displayed the best activity among them with an $\mathrm{IC}_{50}$ value of $0.097 \mu \mathrm{mol} / \mathrm{mL}$ against HEPG2 cells (Song et al., 2012).

\section{AN OVERVIEW OF CYTOTOXICITY RESULTS}

As discussed before in different sections in this review article, a total of 199 compounds isolated from marine fungi have 
shown considerable promise as cytotoxic agents with potential to be developed as anticancer agents in recent years. About half of these compounds have been known to be isoloated from terrestrial or other natural sources previously but they have been reported to be isolated from the marine soruces for the first time. The Supplementary Table 1 outlines the novelty of these compounds with known previous anticancer acitivities, if any. A number of compounds reported in this review article have shown considerable anticancer activity comparable to positive controls (which are currently used anticancer drugs). Many of these metabolites have displayed inhibitory concentrations in the low micromolar range which obviously mark their potential to be developed as anticancer drugs. However, there is a definite need to improve these inhibitory concentrations since lower dosage would help in eliminating undesired side effects. The exploration in this direction has to be a two pronged approach: one, where the actual cellular targets that lead to cytotoxic effects need to be identified while the other, needs to focus on identifying the structural moieties that are responsible for cytotoxicity. The latter effort would lead to structure-activity based drug design programs to alter chemical functionalities in order to achieve higher efficacy.

Additionally, since several of these metabolites possess structural features (such as compounds 84, 88, 116, 119, 129, 131, 192, and 196) that would enable binding to DNA and RNA, cancer targets that involve nucleic acid recognition should be probed. For example, chromosomal DNA ends in humans, which are rich in guanines, have been shown to form a unique four stranded structures called G-quadruplexes. Both in vitro and in vivo studies have shown the formation of these noncanonical structures which use assembly of four guanines (called G-tetrads), hydrogen bonded in a Hoogsteen fashion (Ranjan et al., 2010). After every cell division, the telomeric DNA gets shortened by certain bases and this process continues until reaching a threshold (called Hayflick limit) where senescence is initiated in a normal cell cycle. However, in the majority of cancer cases, a ribonucleoprotein called telomerase gets activated. The telomerase contains an RNA unit complementary to human telomeric repeat sequence TTAGGG. Binding of this RNA unit of telomerase initiates reverse transcription process to regenerate the curtailed telomere (Camarena et al., 2007; Fakhoury et al., 2007). Many research efforts have, therefore, targeted inhibiting/disrupting telomerase interaction with the telomeric DNA as a means to develop new therapies for cancer treatment (Mergny and Hélène, 1998). One of the ways in which this inhibition can be achieved, is by folding the telomeric ends as stable G-quadruplex structures since telomerase recognizes only the linear form of the telomeric DNA. As a result, small molecules that target these G-quadruplex structures have been tested to see if they could function as inhibitors of telomerase interaction. A number of small molecule inhibitors have been reported that bind to G-quadruplexes and enhance their stability (Xue et al., 2011; Ranjan and Arya, 2013; Ranjan et al., 2013). Such stabilizations are known to disfavor telomerase binding and thereby stopping the telomere regeneration. An important feature of G-quadruplex stabilization by small molecule is making stabilizing interactions with the G-tetrads by means of $\pi$-bonding. Some other molecules have shown interactions exclusively with the grooves whereas few have shown interactions both with the tetrads and the grooves. Several of the molecules reported in this review have features that would enable binding both with the G-tetrads and the grooves (for example compound 116). Furthermore, topoisomerases are enzymes that remove supercoiling in DNA during the replication process and repairs strand breaks (Tse-Dinh, 2009; Pommier, 2013). Human DNA topoisomerase has been an attractive cancer target and anticancer drug camptothecin is known to elicit its effect by forming a ternary complex between the enzyme and the DNA. Some of the molecules reported in this review (e.g., compound 194) have already shown topoisomerase inhibitory function. Stalling topoisomerase functions by its stabilization with small molecules is another target for anticancer therapy. Since several of these molecules possess structural features that would enable binding to nucleic acids, a screen that targets all forms of nucleic acid structures should be done. This would not only identify the lead compounds for cancer therapy but would also result in identifying the compound that could be of potential use in antibacterial and antiviral therapy.

In addition to this, there are many new discoveries that could have protein targets within the cancer cells. In fact, the majority of FDA approved anticancer drugs target proteins such as cyclin dependent kinases and histone deacytylase. Could these proteins targets be the potential mechanism by which these metabolites induce cytotoxicity? For some of the compounds $(64,65,168), \mathrm{Bcl}-2$ downregulation was established as one factor that led to the apoptosis. Do these metabolites function by upregulation of tumor suppressor proteins such as p53 and Bax? The curiosities can be answered only when all protein targets are screened for binding; at least for the ones whose cellular functioning is fairly understood. This would usher a new beginning in the development of natural product based small molecules and possibly identify structural motifs that target specific regions in the protein binding pockets. Such leads can then be used to launch structure activity relationship programs to improve the potency of these leads whose inhibitory concentrations are mostly in the micromolar range. Overall, the discoveries presented in this review highlights many structural classes including some new skeletons that these metabolites produce, which have potential to be developed as clinically useful anticancer drugs. However, in the absence of more detailed studies that focuses on deciphering the cellular events that lead to cell death, their true potential as an anticancer compound might remain to be under-appreciated.

\section{CONCLUSIONS AND PERSPECTIVES}

Marine life has been the source of several clinically useful drugs. The findings covered in this review highlight the discoveries of many new natural small molecules, some of them with novel skeletons, that have anticancer activity against a variety of cancer cell lines. The anticancer activity of these compounds is varied with inhibitory concentrations ranging from low to high micromolar concentrations. Some of these metabolites have 
inhibitory concentrations comparable or better than some of the currently used anticancer drugs. Clearly, these leads have not been explored in detail to determine the actual cellular targets that result in the cytotoxicity and that has been an area whose complete exploration may result in a paradigm shift in the current drug discovery efforts. However, other parallel efforts are needed to facilitate and accentuate marine based drug discovery. One such need is setting-up national and international centers for culture collection since many of the new metabolites reported here have been collected from harsh and hostile environments where the human reach is not easily achievable. This would also help not just in retaining these precious cultures but also in allowing wider reach of these metabolites to specialized groups. A major impediment in marine based drug discovery and, in general, natural product based drug discovery has been the lack of centers that foster programs at the interface of chemistry and biology. Clearly, such specialized centers that have expertise both in chemistry and biology could help in realizing true properties of these metabolites. Morever, lack of complete taxonomy details of the new species and bureaucratic difficulties in the implementation of Nagoya protocol hinder smooth access of knowledge and resources. Therefore, international agreements that clearly address these problems and seek solutions to it, could also greatly help in the smooth exchange of resources. Another

\section{REFERENCES}

Agrawal, S., Adholeya, A., and Deshmukh, S. K. (2016). The pharmacological potential of non-ribosomal peptides from marine sponge and tunicates. Front. Pharmacol. 25:333. doi: 10.3389/fphar.2016.00333

Almeida, C., Hemberger, Y., Schmitt, S. M., Bouhired, S., Natesan, L., Kehraus, S., et al. (2012). Marilines A-C: novel phthalimidines from the sponge-derived fungus Stachylidium sp. Chem. Eur. J. 18, 8827-8834. doi: $10.1002 /$ chem. 201103278

Ayyad, S. E., Katoua, D. F., Alarif, W. M., Sobahi, T. R., Aly, M. M., Shaala, L. A., et al. (2015). Two new polyacetylene derivatives from the red sea sponge Xestospongia sp. Z. Naturforsch. C. Bio. Sci. 70, 297-303. doi: 10.1515/znc-2015-5015

Bao, J., Luo, J. F., Qin, X. C., Xu, X. Y., Zhang, X. Y., Tu, Z. C., et al. (2014). Dihydrothiophene-condensed chromones from a marine-derived fungus Penicillium oxalicum and their structure-bioactivity relationship. Bioorg. Med. Chem. Lett. 24, 2433-2436. doi: 10.1016/j.bmcl.2014.04.028

Bhadury, P., Mohammad, B. T., and Wright, P. C. (2006). The current status of natural products from marine fungi and their potential as anti-infective agents. J. Ind. Microbiol. Biotechnol. 33, 325-337. doi: 10.1007/s10295-005-0070-3

Bugni, T. S., and Ireland, C. M. (2004). Marine-derived fungi: a chemically and biologically diverse group of microorganisms. Nat. Prod. Rep. 21, 143-163. doi: $10.1039 / \mathrm{B} 301926 \mathrm{H}$

Butler, M. S., Robertson, A. A., and Cooper, M. A. (2014). Natural product and natural product derived drugs in clinical trials. Nat. Prod. Rep. 31, 1612-1661. doi: 10.1039/C4NP00064A

Cardoso-Martinez, F., de la Rosa, J. M., Diaz-Marrero, A. R., Darias, J., D'Croz, L., Cerella, C., et al. (2015). Oximoaspergillimide, a fungal derivative from a marine isolate of Aspergillus sp. Eur. J. Org. Chem. 10, 2256-2261. doi: $10.1002 /$ ejoc. 201403668

Chen, G., Wang, H. F., and Pei, Y. H. (2014). Secondary metabolites from marine-derived microorganisms, J. Asian. Nat. Prod. Res. 16, 105-122. doi: $10.1080 / 10286020.2013 .855202$

Chen, H., Zhu, X., Zhong, L. L., Yang, B., Li, J., Wu, J. H., et al. (2012). Synthesis and antitumor activities of derivatives of the marine mangrove fungal metabolite deoxybostrycin. Mar. Drugs 10, 2715-2728. doi: 10.3390/md10122715 important improvement in the area would be developing sustainable biochemical production processes of the screening hits as demonstrated in the case of anticancer compounds Scopularide A and B (Yu et al., 2008; Kramer et al., 2014). Additionally, efforts should also be initiated to look beyond anticancer properties of these molecules.

\section{AUTHOR CONTRIBUTIONS}

SD, VP, and NR reviewed the contents critically. VP and NR drew chemical structures and assisted in the preparation of Supplementary Table 1 . SD and NR wrote the review.

\section{ACKNOWLEDGMENTS}

The authors are thankful to Dr. Alok Adholeya, Director, Sustainable Agriculture Division, The Energy and Resources Institute (India) for continuous support.

\section{SUPPLEMENTARY MATERIAL}

The Supplementary Material for this article can be found online at: https://www.frontiersin.org/articles/10.3389/fmicb. 2017.02536/full\#supplementary-material

Chen, L., Zhang, W. W., Zheng, Q. H., Liu, Q. Y., Zhong, P., Hu, X., et al. (2013). Aculeatusquinones A-D, novel metabolites from the marine-derived fungus Aspergillus aculeatus. Heterocycles 87, 861-868. doi: 10.3987/COM-13-12667

Chen, S., Chen, D., Cai, R., Cui, H., Long, Y., Lu, Y., et al. (2016). Cytotoxic and antibacterial preussomerins from the mangrove endophytic fungus Lasiodiplodia theobromae ZJ-HQ1. J. Nat. Prod. 79, 2397-2402. doi: 10.1021/acs.jnatprod.6b00639

Chen, X. W., Li, C.W., Cui, C. B., Hua, W., Zhu, T. J., and Gu, Q. Q. (2014). Nine new and five known polyketides derived from a deep sea-sourced Aspergillus sp., 16-02-1. Mar. Drugs. 12, 3116-3137. doi: 10.3390/md12063116

Chokpaiboon, S., Choodej, S., Boonyuen, N., Teerawatananond, T., and Pudhom, K. (2016). Highly oxygenated chromones from mangrove-derived endophytic fungus Rhytidhysteron rufulum. Phytochemistry 122, 172-177. doi: 10.1016/j.phytochem.2015.12.010

Cui, X., Li, C., Wu, C., and Hua, W. (2013). Metabolites of Paecilomyces lilacinus ZBY-1 from deep-sea water and their antitumor activity. J. Int. Pharm. Res. 40, 177-186.

Debbab, A., Aly, A. H., Edrada-Ebel, R., Wray, V., Muller, W. E. G., Totzke, F., et al. (2009). Bioactive metabolites from endophytic fungus Stemphylium globuliferum isolated from Mentha pulegium J. Nat. Prod. 72, 626-631. doi: 10.1021/np8004997

Debbab, A., Aly, A. H., Edrada-Ebel, R., Wray, V., Pretsch, A., Pescitelli, G., et al. (2012). New anthracene derivatives - structure elucidation and antimicrobial activity. Eur. J. Org. Chem. 2012, 1351-1359. doi: 10.1002/ejoc.201101442

Deng, C., Huang, C., Wu, Q., Pang, J., and Lin, Y. (2013). A new sesquiterpene from the mangrove endophytic fungus Aspergillus terreus (No. GX7-3B). Nat. Prod. Res. 27, 1882-1887. doi: 10.1080/14786419.2013.778847

Deng, C. M., Liu, S. X., Huang, C. H., Pang, J. Y., and Lin, Y. C. (2013). Secondary metabolites of a mangrove endophytic fungus Aspergillus terreus (No. GX7-3B) from the South China Sea. Mar. Drugs. 11, 2616-2624. doi: $10.3390 / \mathrm{md} 11072616$

Deshmukh, S. K., Prakash, V., and Ranjan, N. (2017). Recent advances in the discovery of bioactive metabolites from Pestalotiopsis. Phytochem. Rev. 16, 883-920. doi: 10.1007/s11101-017-9495-3

Dong, Y., Cui, C. B., Li, C. W., Hua, W., Wu, C., Zhu, T. J., et al. (2014). Activation of dormant secondary metabolite production by introducing 
neomycin resistance into the deep-sea fungus Aspergillus versicolor ZBY-3. Mar. Drugs 12, 4326-4352. doi: 10.3390/md12084326

Du, X. P., and Su, W. J. (2014). Two new polyketides from mangrove endophytic fungus Dothiorella sp. Chem. Nat. Compd. 50, 214-216. doi: 10.1007/s10600-014-0915-y

Eamvijarn, A., Gomes, N. M., Dethoup, T., Buaruang, J., Manoch, L., Silva, A., et al. (2013). Bioactive meroditerpenes and indole alkaloids from the soil fungus Neosartorya fischeri (KUFC 6344), and the marine-derived fungi Neosartorya laciniosa (KUFC 7896) and Neosartorya tsunodae (KUFC 9213). Tetrahedron 69, 8583-8591. doi: 10.1016/j.tet.2013.07.078

Ebrahim, W., Kjer, J., El Amrani, M., Wray, V., Lin, W., Ebel, R., et al. (2012). Pullularins E and F, two new peptides from the endophytic fungus Bionectria ochroleuca isolated from the mangrove plant Sonneratia caseolaris. Mar. Drugs 10, 1081-1091. doi: 10.3390/md10051081

Fakhoury, J., Nimmo, G. A., and Autexier, C. (2007). Harnessing telomerase in cancer therapeutics. Anti Cancer Agents Med. Chem. 7, 475-483. doi: $10.2174 / 187152007781058622$

Fang, W., Lin, X., Zhou, X., Wan, J., Lu, X., Yang, B., et al. (2014). Cytotoxic and antiviral nitrobenzoyl sesquiterpenoids from the marinederived fungus Aspergillus ochraceus Jcma1F17, Med.Chem.Comm. 5, 701-705. doi: $10.1039 / \mathrm{c} 3 \mathrm{md} 00371 \mathrm{j}$

Fredimoses, M., Zhou, X., Ai, W., Tian, X., Yang, B., Lin, X., et al. (2015). Westerdijkin A, a new hydroxyphenylacetic acid derivative from deep sea fungus Aspergillus westerdijkiae SCSIO 05233. Nat. Prod. Res. 29, 158-162. doi: 10.1080/14786419.2014.968154

Gao, H., Zhou, L., Cai, S., Zhang, G., Zhu, T., Gu, Q., et al. (2013b). Diorcinols BE, new prenylated diphenyl ethers from the marine-derived fungus Aspergillus versicolor ZLN-60, J. Antibiot. 66(9), 539-542. doi: 10.1038/ja.2013.40

Gao, H., Zhou, L., Li, D., Gu, Q., and Zhu, T. J. (2013a). New cytotoxic metabolites from the marine-derived fungus Penicillium sp. ZLN29. Helv. Chim. Acta 96, 514-519. doi: 10.1002/hlca.201200596

Gao, S. S., Li, X. M., Williams, K., Proksch, P., Ji, N. Y., and Wang, B. G. (2016b). Rhizovarins A-F, indole-diterpenes from the mangrove-derived endophytic fungus Mucor irregularis QEN-189, J. Nat. Prod. 79, 2066-2074. doi: 10.1021/acs.jnatprod.6b00403

Gao, X. W., Liu, H. X., Sun, Z. H., Chen, Y. C., Tan, Y. Z., and Zhang, W. M. (2016a). Secondary metabolites from the deep-sea derived fungus Acaromyces ingoldii FS121. Molecules 21, 371/1-371/7. doi: 10.3390/molecules 21040371

Gomes, N. G., Lefranc, F., Kijjoa, A., and Kiss, R. (2015). Can some marine-derived fungal metabolites become actual anticancer agents? Mar. Drugs 13, 3950-3991. doi: $10.3390 / \mathrm{md} 13063950$

Guo, L., Huang, T., Hu, B., and Wang, C. (2016). Bioactivity-guided isolation and characterization of antitumor active compound from marine-derived fungus Penicillium chrysogenum HGQ6. Adv. J. Food. Sci. Technol. 10, 353-355. doi: 10.19026/ajfst.10.2081

Hammerschmidt, L., Debbab, A., Ngoc, T. D., Wray, V., Hemphil, C. P., Lin, W. H., et al. (2014). Polyketides from the mangrove-derived endophytic fungus Acremonium strictum. Tetrahedron Lett. 55, 3463-3468. doi: 10.1016/j.tetlet.2014.04.063

He, F., Bao, J., Zhang, X. Y., Tu, Z. C., Shi, Y. M., and Qi, S. H. (2013). Asperterrestide A, a Cytotoxic Cyclic Tetrapeptide from the marinederived fungus Aspergillus terreus SCSGAF0162. J. Nat. Prod. 76, 1182-1186. doi: $10.1021 / \mathrm{np} 300897 \mathrm{v}$

He, F., Sun, Y. L., Liu, K. S., Zhang, X. Y., Qian, P. Y., Wang, Y. F., et al. (2012). Indole alkaloids from marine-derived fungus Aspergillus sydowii SCSIO 00305, J. Antibiot. 65, 109-111. doi: 10.1038/ja.2011.117

Hua, W., Chen, X., and Cui, X. (2011). "Preliminary study of deep-sea fungi and their bioactive secondary metabolites," in Proceedings of the Eleventh National Symposia of Chinese Medicine and Natural Products (Shenyang), 46.

Huang, H., Wang, F., Luo, M., Chen, Y., Song, Y., Zhang, W., et al. (2012). Halogenated anthraquinones from the marine-derived fungus Aspergillus sp. SCSIO F063. J. Nat. Prod. 75, 1346-1352. doi: 10.1021/np3002699

Huang, J., Xu, J., Wang, Z., Khan, D., Niaz, S. I., Zhu, Y., et al. (2017). New lasiodiplodins from mangrove endophytic fungus Lasiodiplodia sp. 318. Nat. Prod. Res. 31, 326-332. doi: 10.1080/14786419.2016.1239096

Huang, Z., Yang, J., Cai, X., She, Z., and Lin, Y. (2012). A new furanocoumarin from the mangrove endophytic fungus Penicillium sp. ZH16. Nat. Prod. Res. 26, 1291-1295. doi: 10.1080/14786419.2011.569502
Huang, Z., Yang, J., Lei, F., She, Z., and Lin, Y. (2013). A new xanthone O-glycoside from the mangrove endophytic fungus Phomopsis sp. Chem. Nat. Compd. 49, 27-30. doi: 10.1007/s10600-013-0497-0

Imhoff, J. F. (2016). Natural products from marine fungi-still an underrepresented resource. Mar. Drugs 14:19. doi: 10.3390/md14010019

Jans, P. E., Mfuh, A. M., Arman, H. D., Shaffer, C. V., Larionov, O. V., and Mooberry, S. L. (2017). Cytotoxicity and mechanism of action of the marinederived fungal metabolite trichodermamide B and synthetic analogues. J. Nat. Prod. 80, 676-683. doi: 10.1021/acs.jnatprod.6b00963

Javed, F., Qadir, M. I., Janbaz, K. H., and Ali, M. (2011). Novel drugs from marine microorganisms. Crit. Rev. Microbiol. 37, 245-249. doi: 10.3109/1040841X.2011.576234

König, G. M., Kehraus, S., Seibert, S. F., Abdel-Lateff, A., and Müller, D. (2006). Natural products from marine organisms and their associated microbes. Chembiochem 7, 229-238. doi: 10.1002/cbic.200500087

Kramer, A., Paun, L., Imhoff, J. F., Kempken, F., and Labes, A. (2014). Development and validation of a fast and optimized screening method for enhanced production of secondary metabolites using the marine Scopulariopsis brevicaulis strain LF580 producing anti-cancer active scopularide A and B. PLoS ONE 9:e103320. doi: 10.1371/journal.pone.0103320

Li, C. S., Li, X. M., Gao, S. S., Lu, Y. H., and Wang, B. G. (2013). Cytotoxic anthranilic acid derivatives from deep sea sediment-derived fungus Penicillium paneum SD-44, Mar. Drugs 11, 3068-3076. doi: 10.3390/md11083068

Li, C.-W., Xia, M. W., Cui, C. B., Peng, J. X., and Li, D. H. (2016). A novel oxaphenalenone, penicimutalidine: activated production of oxaphenalenones by the diethyl sulphate mutagenesis of marine-derived fungus Penicillium purpurogenum G59. RSC Adv. 6, 82277-82281. doi: 10.1039/C6RA $17087 \mathrm{~K}$

Li, H.-J., Jiang, W. H., Liang, W. L., Huang, J. X., Mo, Y. F., Ding, Y. Q., et al. (2014). Induced marine fungus Chondrostereum sp. as a means of producing new sesquiterpenoids chondrosterins I and J by using glycerol as the carbon source. Mar. Drugs. 12, 167-175. doi: 10.3390/md12010167

Li, J., Xue, Y., Yuan, J., Lu, Y., Zhu, X., Lin, Y., et al. (2016). Lasiodiplodins from mangrove endophytic fungus Lasiodiplodia sp., 318\#. Nat. Prod. Res. 30, 755-760. doi: 10.1080/14786419.2015.1062762

Li, J., Yang, X., Lin, Y., Yuan, J., Lu, Y., Zhu, X., et al. (2014). Meroterpenes and azaphilones from marine mangrove endophytic fungus Penicillium 303 \#. Fitoterapia 97, 241-246. doi: 10.1016/j.fitote.2014.06.011

Li, P., Fan, Y., Chen, H., Chao, Y., Du, N., and Chen, J. (2016). Phenylquinolinones with antitumor activity from the Indian ocean-derived fungus Aspergillus versicolor Y31-2. Chinese J. Oceanol. Limnol. 34, 1072-1075. doi: 10.1007/s00343-016-5097-y

Li, X., Li, X. M., Li, X. D., Xu, G. M., Liu, Y., and Wang, B. G. (2016). 20-Nor-isopimarane cycloethers from the deep-sea sedimentderived fungus Aspergillus wentii SD-310. RSC Adv. 6, 75981-75987. doi: 10.1039/C6RA17638K

Li, X.-D., Li, X., Li, X. M., Xu, G. M., Zhang, P., Meng, L. H., et al. (2016). Tetranorlabdane diterpenoids from the deep sea sedimentderived fungus Aspergillus wentii SD-310. Planta Med. 82, 877-881. doi: 10.1055/s-0042-102965

Li, Y., Ye, D., Shao, Z., Cui, C., and Che, Y. (2012). A sterol and spiroditerpenoids from a Penicillium sp. isolated from a deep sea sediment sample. Mar. Drugs. 10, 497-508. doi: 10.3390/md10020497

Li, Y.-X., Himaya, S. W. A., Dewapriya, P., Kim, H. J., and Kim, S. K. (2014). Anti-proliferative effects of isosclerone isolated from marine fungus Aspergillus fumigatus in MCF-7 human breast cancer cells. Process. Biochem. 49, 2292-2298. doi: 10.1016/j.procbio.2014.08.016

Liang, X., Zhang, X. Y., Nong, X. H., Wang, J., Huang, Z. H., and Qi, S. H. (2016). Eight linear peptides from the deep-sea-derived fungus Simplicillium obclavatum EIODSF 020. Tetrahedron 72, 3092-3097. doi: $10.1016 /$ j.tet.2016.04.032

Lin, A., Wu, G., Gu, Q., Zhu, T., and Li, D. (2014). New eremophilane-type sesquiterpenes from an Antarctic deep-sea derived fungus Penicillium sp. PR19 N-1. Arch. Pharm. Res. 37, 839-844. doi: 10.1007/s12272-013-0246-8

Liu, D., Li, X. M., Li, C. S., and Wang, B. G. (2013). Nigerasterols A and $\mathrm{B}$, antiproliferative sterols from the mangrove-derived endophytic fungus Aspergillus niger MA-132. Helv. Chim. Acta 96, 1055-1061. doi: $10.1002 /$ hlca.201200332 
Liu, H., Zhang, L., Chen, Y., Li, S., Tan, G., Sun, Z., et al. (2017). Cytotoxic pimarane-type diterpenes from the marine sediment-derived fungus Eutypella sp. FS46. Nat. Prod. Res. 31, 404-410, doi: 10.1080/14786419.2016. 1169418

Liu, Q. Y., Zhou, T., Zhao, Y. Y., Chen, L., Gong, M. W., Xia, Q. W., et al. (2015). Antitumor effects and related mechanisms of penicitrinine A, a novel alkaloid with a unique spiro skeleton from the marine fungus Penicillium citrinum. Mar. Drugs 13, 4733-4753. doi: 10.3390/md13084733

Liu, S., Dai, H., Makhloufi, G., Heering, C., Janiak, C., Hartmann, R., et al. (2016). Cytotoxic 14-membered macrolides from a mangrove-derived endophytic fungus Pestalotiopsis microspore. J. Nat. Prod. 79, 2332-2340. doi: 10.1021/acs.jnatprod.6b00473

Liu, Y., Marmann, A., Abdel-Aziz, M. S., Wang, C. Y., Müller, W. E. G., Lin, W. H., et al. (2015). Tetrahydroanthraquinone derivatives from the endophytic fungus Stemphylium globuliferum. Eur. J. Org. Chem. 2015, 26462653. doi: 10.1002/ejoc.201500079

Liu, Y., Zhao, S., Ding, W., Wang, P., Yang, X., and Xu, J. (2014). Methylthioaspochalasins from a marine-derived fungus Aspergillus sp. Mar. Drugs. 12, 5124-5131. doi: 10.3390/md12105124

Lv, C., Hong, Y., Miao, L., Li, C., Xu, G., Wei, S., et al. (2013). Wentilactone A as a novel potential antitumor agent induces apoptosis and $\mathrm{G} 2 / \mathrm{M}$ arrest of human lung carcinoma cells, and is mediated by HRas-GTP accumulation to excessively activate the Ras/Raf/ERK/p53-p21 pathway. Cell Death Dis. 4:e952. doi: 10.1038/cddis.2013.484

Mahé, S., Rédou, V., Calvez, T. L., Vandenkoornhuyse, P., and Burgaud, G. (2013). "Fungi in deep-sea environments and metagenomics," in The Ecological Genomics of Fungi, ed F. Martin (Hoboken, NJ: John Wiley \& Sons Inc.), 325-354.

Meng, L. H., Wang, C. Y., Mandi, A., Li, X. M., Hu, X. Y., Kassack, M. U., et al. (2016). Three diketopiperazine alkaloids with spirocyclic skeletons and one bisthiodiketopiperazine derivative from the mangrove-derived endophytic fungus Penicillium brocae MA-231. Org. Lett. 18, 5304-5307. doi: 10.1021/acs.orglett.6b02620

Mergny, J. L., and Hélène, C. (1998). G-quadruplex DNA: a target for drug design. Nat. Med. 4, 1366-1367. doi: 10.1038/3949

Mishra, P. D., Verekar, S. A., Deshmukh, S. K., Joshi, K. S., Fiebig, H. H., and Kelter, G. (2015). Altersolanol A: a selective cytotoxic anthraquinone from a Phomopsis sp. Lett. Appl. Microbiol. 60, 387-391. doi: 10.1111/lam.12384

Molinski, T. F., Dalisay, D. S., Lievens, S. L., and Saludes, J. P. (2009). Drug development from marine natural products. Nat. Rev. Drug Disc. 8:69. doi: $10.1038 / \mathrm{nrd} 2487$

Moussa, M., Ebrahim, W., El-Neketi, M., Mandi, A., Kurtan, T., Hartmann, R., et al. (2016). Tetrahydroanthraquinone derivatives from the mangrove-derived endophytic fungus Stemphylium globuliferum. Tetrahedron Lett. 57, 4074-4078. doi: 10.1016/j.tetlet.2016.07.091

Passaes C. P., and Sáez-Cirión, A. (2014). HIV cure research: advances and prospects. Virology 454-455, 340-352. doi: 10.1016/j.virol.2014. 02.021

Pejin, B., and Maja, K. (2017). "Antitumor natural products of marine-derived fungi," in Fungal Metab, eds J. M. Mérillon and K. G. Ramawat (Springer International Publishing), 1-28. doi: 10.1007/978-3-319-19456-1_25-1

Peng, J., Zhang, X. Y., Tu, Z. C., Xu, X. Y., and Qi, S. H. (2013). Alkaloids from the deep-sea-derived fungus Aspergillus westerdijkiae DFFSCS013. J. Nat. Prod. 76, 983-987. doi: $10.1021 / \mathrm{np} 400132 \mathrm{~m}$

Perez, H. C. F., Daletos, G., Liu, Z., Lin, W., and Proksch, P. (2016). Polyketides from the mangrove-derived fungal endophyte Pestalotiopsis clavispora. Tetrahedron Lett. 57, 2078-2083. doi: 10.1016/j.tetlet.2016.03.101

Pommier, Y. (2013). Drugging topoisomerases: lessons and challenges. ACS Chem. Biol. 8, 82-95. doi: 10.1021/cb300648v

Ranjan, N., and Arya, D. P. (2013). Targeting C-myc G-quadruplex: dual recognition by aminosugar-bisbenzimidazoles with varying linker lengths. Molecules 18, 14228-40. doi: 10.3390/molecules 181114228

Ranjan, N., Andreasen, K. F., Kumar, S., Hyde-Volpe, D., and Arya, D. P. (2010). Aminoglycoside binding to oxytricha nova telomeric DNA. Biochemistry 49, 9891-9903. doi: 10.1021/bi101517e

Ranjan, N., Davis, E., Xue, L., and Arya, D. P. (2013). Dual recognition of the human telomeric G-quadruplex by a neomycin-anthraquinone conjugate. Chem. Commun. 49, 5796-5798. doi: 10.1039/C3CC42721H
Saleem, M., Ali, M. S., Hussain, S., Jabbar, A., Ashraf, M., and Lee, Y. S. (2007). Marine natural products of fungal origin. Nat. Prod. Rep. 24, 1142-1152. doi: $10.1039 / \mathrm{b} 607254 \mathrm{~m}$

Sampedro Camarena, F., Cano Serral, G., and Sampedro Santaló, F. (2007). Telomerase and telomere dynamics in ageing and cancer: current status and future directions. Clin. Transl. Oncol. 9, 145-154. doi: 10.1007/s12094-007-0028-1

Saraiva, N. N., Rodrigues, B. S., Jimenez, P. C., Guimarães, L. A., Torres, M. C. M., Rodrigues-Filho, E., et al. (2015). Cytotoxic compounds from the marinederived fungus Aspergillus sp. recovered from the sediments of the Brazilian coast. Nat. Prod. Res. 29, 1545-1550. doi: 10.1080/14786419.2014.987772

Shang, Z., Li, L., Espósito, B. P., Salim, A. A., Khalil, Z. G., Quezada, M., et al. (2015). New PKS-NRPS tetramic acids and pyridinone from an Australian marine-derived fungus Chaunopycnis sp. Org. Biomol. Chem. 13, 7795-7802. doi: 10.1039/C5OB01058F

Shang, Z., Li, X. M., Li, C. S., and Wang, B. G. (2012b). Diverse secondary metabolites produced by marine-derived fungus Nigrospora sp. MA75 on various vulture media. Chem. Biodivers. 9, 1338-1348. doi: 10.1002/cbdv.201100216

Shang, Z., Li, X., Meng, L., Li, C., Gao, S., Huang, C., et al. (2012a). Chemical profile of the secondary metabolites produced by a deep-sea sediment-derived fungus Penicillium commune SD-118. Chin. J. Oceanol. Limnol. 30, 305-314. doi: 10.1007/s00343-012-1075-1

Singh, R., Sharma, M., Joshi, P., and Rawat, D. S. (2008). Clinical status of anticancer agents derived from marine sources. Anti Cancer Agents Med.Chem. 8, 603-617. doi: 10.2174/1871520610808060603

Sithranga, N. B., and Kathiresan, K. (2011). Anticancer drugs from marine flora: an overview. J. Oncol. 2010:18. doi: 10.1155/2010/214186

Song, F., Ren, B., Yu, K., Chen, C., Guo, H., Yang, N., et al. (2012). Quinazolin-4-one coupled with pyrrolidin-2-iminium alkaloids from marinederived fungus Penicillium aurantiogriseum. Mar. Drugs. 10, 1297-1306. doi: $10.3390 / \mathrm{md} 10061297$

Sun, H.-F., Li, X. M., Meng, L., Cui, C. M., Gao, S. S., Li, C. S., et al. (2012). Asperolides A-C, tetranorlabdene diterpenoids from the marine algaderived endophytic fungus Aspergillus wentii EN-48. J. Nat. Prod. 75, 148-152. doi: $10.1021 / \mathrm{np} 2006742$

Sun, L., Li, D., Tao, M., Chem, Y., Dan, F., and Zhang, W. (2012). Scopararanes C-G: new oxygenated pimarane diterpenes from the marine sediment-derived fungus Eutypella scoparia FS26. Mar. Drugs 10, 539-550. doi: $10.3390 / \mathrm{md} 10030539$

Sun, L.-L., Shao, C. L., Chen, J. F., Guo, Z. Y., Fu, X. M., Chen, M., et al. (2012). New bisabolane sesquiterpenoids from a marine-derived fungus Aspergillus sp. isolated from the sponge Xestospongia testudinaria. Bioorg. Med. Chem. Lett. 22, 1326-1329. doi: 10.1016/j.bmcl.2011.12.083

Sun, Y. L., Bao, J., Liu, K. S., Zhang, X. Y., He, F., Wang, Y. F., et al. (2013). Cytotoxic dihydrothiophene-condensed chromones from the marine-derived fungus Penicillium oxalicum. Planta Med. 79, 1474-1479. doi: $10.1055 / \mathrm{s}-0033-1350805$

Swathi, J., Narendra, K., Sowjanya, K. M., and Satya, A. K. (2013). Evaluation of biologically active molecules isolated from obligate marine fungi. Mintage J. Pharm. Med. Sci. 2, 45-47.

Tan, Q. W., Ouyang, M. A., Shen, S., and Li, W. (2012). Bioactive metabolites from a marine-derived strain of the fungus Neosartorya fischeri. Nat. Prod. Res. 26, 1402-1407. doi: 10.1080/14786419.2011.592834

Tao, Y. W., Lin, Y. C., She, Z. G., Lin, M. T., Chen, P. X., and Zhang, J. Y. (2015). Anticancer activity and mechanism investigation of beauvericin isolated from secondary metabolites of the mangrove endophytic fungi. Anticancer. Agents. Med. Chem. 15, 258-266. doi: 10.2174/1871520614666140825112255

Teiten, M. H., Mack, F., Debbab, A., Aly, A. H., Dicato, M., Proksch, P., et al. (2013). Anticancer effect of altersolanol A, a metabolite produced by the endophytic fungus Stemphylium globuliferum, mediated by its proapoptotic and anti-invasive potential via the inhibition of NF-кB activity. Bioorg. Med. Chem. 21, 3850-3858. doi: 10.1016/j.bmc.2013.04.024

Tse-Dinh, Y. (2009). Bacterial topoisomerase I as a target for discovery of antibacterial compounds. Nucleic Acids Res. 37, 731-737. doi: $10.1093 / \mathrm{nar} / \mathrm{gkn} 936$

Wang, F. Z., Huang, Z., Shi, X. F., Chen, Y. C., Zhang, W. M., Tian, X. P., et al. (2012). Cytotoxic indole diketopiperazines from the deep sea-derived fungus 
Acrostalagmus luteoalbus SCSIO F457. Bioorg. Med. Chem. Lett. 22, 7265-7267. doi: 10.1016/j.bmcl.2012.08.115

Wang, J., Wang, Z., Ju, Z., Wan, J., Liao, S., Lin, X., et al. (2015). Cytotoxic cytochalasins from marine-derived fungus Arthrinium arundinis. Planta Med. 81, 160-166. doi: 10.1055/s-0034-1383403

Wang, N., Cui, C. B., and Li, C. W. (2016). A new cyclic dipeptide penicimutide: the activated production of cyclic dipeptides by introduction of neomycinresistance in the marine-derived fungus Penicillium purpurogenum G59. Arch. Pharm. Res. 39, 762-770. doi: 10.1007/s12272-016-0751-7

Wang, W.-J., Li, D. Y., Li, Y. C., Hua, H. M., Ma, E. L., and Li, Z. L. (2014). Caryophyllene sesquiterpenes from the marine-derived fungus Ascotricha sp. ZJ-M-5 by the one strain-many compounds strategy. J. Nat. Prod. 77, 1367-1371. doi: 10.1021/np500110z

Wang, Y., Qi, X., Li, D., Zhu, T., Mo, X., and Li, J. (2014). Anticancer efficacy and absorption, distribution, metabolism, and toxicity studies of Aspergiolide A in early drug development. Drug Design Develop. Ther. 8, 1965-1977. doi: 10.2147/DDDT.S64989

Wijesekara, I., Li, Y. X., Vo, T. S., Van Ta, Q., Ngo, D. H., and Kim, S. K. (2013). Induction of apoptosis in human cervical carcinoma HeLa cells by neoechinulin A from marine-derived fungus Microsporum sp. Process. Biochem. 48, 68-72. doi: 10.1016/j.procbio.2012.11.012

Wijesekara, I., Zhang, C., Van Ta, Q., Vo, T. S., Li, Y. X., and Kim, S. K. (2014). Physcion from marine-derived fungus Microsporum sp. induces apoptosis in human cervical carcinoma HeLa cells. Microbiol. Res. 169, 255-261. doi: 10.1016/j.micres.2013.09.001

Wu, B., Chen, G., Liu, Z. G., and Pei, Y. (2015). Two new alkaloids from a marine-derived fungus Neosartorya fischeri. Rec. Nat. Prod. 9, 271-275.

Wu, B., Wiese, J., Wenzel-Storjohann, A., Malien, S., Schmaljohann, R., and Imhoff, J. F. (2016). Engyodontochones, antibiotic polyketides from the marine fungus Engyodontium album strain LF069. Chemistry 22, 7452-7462. doi: 10.1002/chem.201600430

Wu, G., Lin, A., Gu, Q., Zhu, T., and Li, D. (2013). Four new chloro-eremophilane sesquiterpenes from an Antarctic deep-sea derived fungus Penicillium sp. PR19N-1. Mar. Drugs 11, 1399-1408. doi: 10.3390/md11041399

Xia, M. W., Cui, C. B., Li, C. W., Wu, C. J., Peng, J. X., and Li, D. H. (2015). Rare Chromones from a fungal mutant of the marine-derived Penicillium purpurogenum G59. Mar. Drugs 13, 5219-5236. doi: 10.3390/md13085219

Xia, X., Zhang, J., Zhang, Y., Wie, F., Liu, X., Jia, A., et al. (2012). Pimarane diterpenes from the fungus Epicoccum sp. HS-1 associated with Apostichopus japonicus. Bioorg. Med. Chem. Lett. 22, 3017-3019. doi: 10.3390/md13031124

Xu, R., Xu, G. M., Li, X. M., Li, C. S., and Wang, B. G. (2015). Characterization of a newly isolated marine fungus Aspergillus dimorphicus for optimized production of the anti-tumor agent wentilactones. Mar. Drugs. 13, 7040-7054. doi: $10.3390 / \mathrm{md} 13117040$

Xue, L., Ranjan, N., and Arya, D. P. (2011). Synthesis and spectroscopic studies of the aminoglycoside (neomycin) perylene conjugate binding to human telomeric DNA. Biochemistry 50, 2838-2849. doi: 10.1021/bi1017304

Yang, J. X., Qiu, S. X., She, Z. G., and Lin, Y. C. (2013b). Metabolites of mangrove endophytic fungus Gx-3a from the south China sea. Guangxi Kexue 20, 168-170.

Yang, J. X., Qiu, S. X., She, Z. G., and Lin, Y. C. (2013a). Metabolites of mangrove endophytic fungus 5094 from the south china sea. Shizhen Guoyi Guoyao 24, 1059-1061. doi: 10.3969/j.issn.1008-0805.2013.05.014

Yang, J. X., Qiu, S. X., She, Z. G., and Lin, Y. C. (2013c). A new xanthone derivative from the marine fungus Phomopsis sp. (No. SK7RN3G1). Chem. Nat. Compd. 49, 246-248. doi: 10.1007/s10600-013-0572-6
Yang, J., Huang, R., Qiu, S. X., She, Z. G., and Lin, Y. C. (2013). A new isobenzofuranone from the mangrove endophytic fungus Penicillium sp. (ZH58). Nat. Prod. Res. 27, 1902-1905. doi: 10.1080/14786419.2013.784870

Yao, Q., Wang, J., Zhang, X., Nong, X., Xu, X., and Qi, S. (2014). Cytotoxic polyketides from the deep-sea-derived fungus Engyodontium album DFFSCS021. Mar. Drugs 12, 5902-5915. doi: 10.3390/md12125902

Yi, L., Cui, C. B., Li, C. W., Peng, J. X., and Gu, Q. Q. (2016). Chromosulfine, a novel cyclopentachromone sulfide produced by a marine-derived fungus after introduction of neomycin resistance. RSC Advances 6, 43975-43979. doi: 10.1039/C6RA06250D

Yu, Z., Lang, G., Kajahn, I., Schmaljohann, R., and Imhoff, J. F. (2008). Scopularides A and B, cyclodepsipeptides from a marine spongederived fungus, Scopulariopsis brevicaulis. J. Nat. Prod. 71, 1052-1054. doi: $10.1021 / \mathrm{np} 070580 \mathrm{e}$

Zeng, Y. B., Gu, H. G., Zuo, W. J., Zhang, L. L., Bai, H. J., Guo, Z. K., et al. (2015). Two new sesquiterpenoids from endophytic fungus J3 isolated from mangrove plant Ceriops tagal. Arch. Pharm. Res. 38, 673-676. doi: 10.1007/s12272-014-0448-8

Zhang, P., Li, X. M., Mao, X. X., Mandi, A., Kurtan, T., and Wang, B. G. (2016). Varioloid A, a new indolyl-6,10b-dihydro-5aH-[1]benzofuro[2,3-b]indole derivative from the marine alga-derived endophytic fungus Paecilomyces variotii EN-291. Beilstein J. Org. Chem. 12, 2012-2018. doi: 10.3762/bjoc.12.188

Zhang, Z., Miao, L., Lv, C., Sun, H., Wei, S., Wang, B., et al. (2013). Wentilactone $B$ induces G2/M phase arrest and apoptosis via the Ras/Raf/MAPK signaling pathway in human hepatoma SMMC-7721 cells. Cell Death Dis. 4:e657. doi: $10.1038 /$ cddis.2013.182

Zhao, Y., Chen, H., Shang, Z., Jiao, B., Yuan, B., Sun, W., et al. (2012). SD118xanthocillin X (1), a novel marine agent extracted from Penicillium commune, induces autophagy through the inhibition of the MEK/ERK pathway. Mar. Drugs 10, 1345-1359. doi: 10.3390/md10061345

Zheng, C., Chen, Y., Jiang, L. L., and Shi, X. M. (2014). Antiproliferative metabolites from the endophytic fungus Penicillium sp. FJ-1 isolated from a mangrove Avicennia marina. Phytochem. Lett. 10, 272-275. doi: 10.1016/j.phytol.2014.10.011

Zhou, S. L., Wang, M., Zhao, H. G., Huang, Y. H., Lin, Y. Y., Tan, G. H., et al. (2016). Penicilazaphilone C, a new antineoplastic and antibacterial azaphilone from the marine fungus Penicillium sclerotiorum. Arch. Pharm. Res. 39, 1621-1627. doi: 10.1007/s12272-016-0828-3

Zhu, M., Zhang, X., Feng, H., Che, Q., Zhu, T., Gu, Q., et al. (2016). Campyridones A-D, pyridone alkaloids from a mangrove endophytic fungus Campylocarpon sp. HDN13-307. Tetrahedron 72, 5679-5683. doi: 10.1016/j.tet.2016.07.080

Zhuravleva, O. I., Afiyatullov, S. S. H., Vishchuk, O. S., Denisenko, V. A., Slinkina, N. N., and Smetanina, O. F. (2012). Decumbenone C, a new cytotoxic decaline derivative from the marine fungus Aspergillus sulphureus KMM 4640. Arch. Pharm. Res. 35, 1757-1762. doi: 10.1007/s12272-012-1007-9

Conflict of Interest Statement: The authors declare that the research was conducted in the absence of any commercial or financial relationships that could be construed as a potential conflict of interest.

Copyright (C) 2018 Deshmukh, Prakash and Ranjan. This is an open-access article distributed under the terms of the Creative Commons Attribution License (CC BY). The use, distribution or reproduction in other forums is permitted, provided the original author(s) or licensor are credited and that the original publication in this journal is cited, in accordance with accepted academic practice. No use, distribution or reproduction is permitted which does not comply with these terms. 